\title{
WestVirginiaUniversity
}

THE RESEARCH REPOSITORY @ WVU

Graduate Theses, Dissertations, and Problem Reports

2021

\section{Current Trends in the Management of Endodontic Emergencies}

Asmi Shah

West Virginia University, as0290@mix.wvu.edu

Follow this and additional works at: https://researchrepository.wvu.edu/etd

Part of the Endodontics and Endodontology Commons

\section{Recommended Citation}

Shah, Asmi, "Current Trends in the Management of Endodontic Emergencies" (2021). Graduate Theses, Dissertations, and Problem Reports. 10318.

https://researchrepository.wvu.edu/etd/10318

This Thesis is protected by copyright and/or related rights. It has been brought to you by the The Research Repository @ WVU with permission from the rights-holder(s). You are free to use this Thesis in any way that is permitted by the copyright and related rights legislation that applies to your use. For other uses you must obtain permission from the rights-holder(s) directly, unless additional rights are indicated by a Creative Commons license in the record and/ or on the work itself. This Thesis has been accepted for inclusion in WVU Graduate Theses, Dissertations, and Problem Reports collection by an authorized administrator of The Research Repository @ WVU. For more information, please contact researchrepository@mail.wvu.edu. 
Graduate Theses, Dissertations, and Problem Reports

2021

Current Trends in the Management of Endodontic Emergencies

Asmi Shah

Follow this and additional works at: https://researchrepository.wvu.edu/etd

Part of the Endodontics and Endodontology Commons 


\title{
Current Trends in the Management of Endodontic Emergencies
}

\author{
Asmi A. Shah, D.D.S \\ the requirements for the degree of \\ Master of Science in Endodontics \\ Samuel O. Dorn, D.D.S, M.S, Chair \\ R. Constance Wiener, D.M.D, PhD \\ Mark A. Byron, D.D.S, M.S \\ Department of Endodontics \\ Morgantown, WV \\ 2021
}

Thesis submitted to the School of Dentistry at West Virginia University in partial fulfillment of

Keywords: endodontics, emergencies, diagnosis, irreversible pulpitis, swelling, pain

Copyright 2021 Asmi A. Shah, D.D.S 


\section{Abstract \\ Current Trends in the Management of Endodontic Emergencies}

Asmi A. Shah

Introduction: The management of endodontic emergencies has changed over the last few decades and varies from practice to practice. This is due to the development of new materials, new irrigation techniques, and new evidence-based research which supports clinical success. An updated questionnaire is necessary to further advance the clinical knowledge in endodontic emergencies based on current practices. Therefore, the purpose of this research is to determine the difference practice modalities between members who are board certified, who are not board certified, and endodontic graduate residents.

Materials and Methods: In 2021, every member of the American Association of Endodontics (n $=3157)$ were asked to complete a short survey about clinical practices and $394(12.5 \%)$ completed the survey. The survey included questions regarding length of time between emergency treatment and definitive treatment, routinely prescribed antibiotics and analgesics, cone beam computed tomography use, level of pulp removal and instrumentation, and treatment modalities for teeth that exhibit swelling and drainage. The collected data were then statistically analyzed.

Results: The overall preference in recommended analgesia was ibuprofen with $99.2 \%$ of all participants indicating that choice. The second most recommended analgesia was acetaminophen. It was recommended by $66.4 \%$ of all participants. The most recommended antibiotic was amoxicillin followed by clindamycin. Participants at all levels of education had similar choices in supplemental anesthesia. Board certified endodontists were more likely than non-board certified endodontists or residents to use a CBCT during endodontic emergencies ( $p<$ $0.05)$. Considering microscope use, board certified endodontists were more likely than non-board certified endodontists or residents to always use a microscope $(\mathrm{p}<0.05)$. Most participants choice to wait 1-2 weeks from initiating treatment to completing treatment, an evidence-based recommendation. Majority of participants instrument to apex using the electronic apex locator, and completed the instrumentation in all 7 diagnoses. Among adjunct treatment, incision and drainage on average was selected over leave tooth open, insert drain, and artifistulation.

Conclusion: Overall, residents and non-board certified endodontists treat patients similarly. The major differences are in CBCT use and microscope. Majority of participants instrument to the electronic apex locator reading and complete instrumentation. One major concern is the use of clindamycin which is no evidence based any longer and requires greater continued education on its prescription use in patients. 


\section{Dedication}

To my parents, Smita and Ashwin, for always supporting me in my decision to pursue dentistry and now endodontics as a specialty. You have always taught me to have a strong academic background while still enjoying life's precious moments. To my brother, Rushi, thank you for always keeping me grounded and lifting my spirits when I did not know I needed it.

To my dear husband, Sumeet, thank you for being my number one supporter. The transition into a new home, a new state, and a new program was not easy but you stayed by my side through it all. As much as West Virginia has grown on me, I am excited for us to start our new chapter together. 


\section{Acknowledgements}

I would like to take this opportunity to thank the following people:

Dr. Mark Byron, thank you for your relentless patience in teaching and educating both the residents and pre-doctoral students. Your efforts do not go unnoticed and your passion for helping others sets a standard that should be followed by everyone. During the height of COVID shutdown when our two senior residents and I were rotating our clinic days, you were here every single day. I will miss our long talks about history, culture, and navigating different personalities.

Dr. Samuel Dorn, thank you for always advocating for the endodontic residents and advocating the standards of excellence. Most of all, thank you for making it a priority to have the CBCT machine installed. Your inclination for technological and clinical advancements in endodontics has motivated me to stay current with my research and not hesitate to try a new approach or a different product. Your dedication to academia is admirable and I hope we can squeeze a few more years out of you.

Dr. R Constance Wiener, thank you for the time and effort you have put into the numerous meetings with me over Zoom and in person. I am constantly amazed by your skills in organization, timeliness, and ability to focus on fine details, despite being a research mentor for many other pre-doc students and residents, in addition to working in the dental clinic. I appreciate the amount of detail and attention you have put into my thesis, as well as keeping me on a schedule and teaching me the SPSS software. I would not have gotten this far without your help.

Dr. Michael Cavender, thank you for taking the time to teach not just me but all the residents how to become more efficient in the clinic. Sharing your private practice experiences - both good and bad - has taught me that this specialty is continually evolving both as a profession and for me as a professional, and sometimes you just have to think out of the box. Although our interaction together will be shorthanded, I have already gained so many valuable lessons and I hope to pick your brain for just a little while longer.

Mr. Chris Waters, thank you for the occasional drop-ins to grin-fully ask how my thesis was going. From the beginning, you always showed so much patience while helping me multiple times to navigate the IRB protocol. You promptly provided me with guidance and resources to assemble my thesis. I will miss the lighthearted conversations and the gentle nudge to complete my thesis. 


\section{Table of Contents}

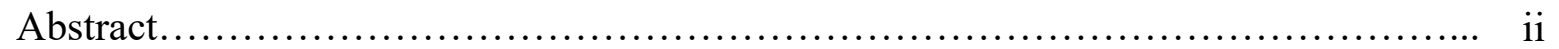

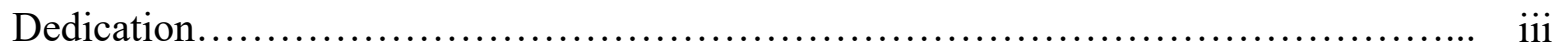

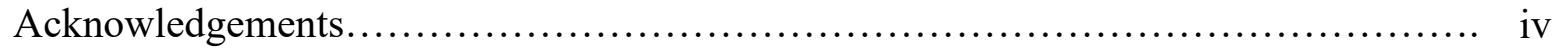

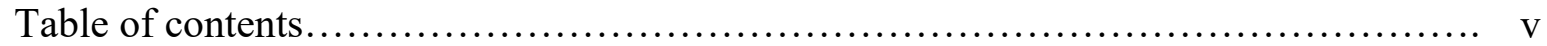

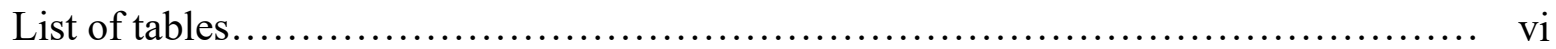

List of symbols, abbreviations, or nomenclature............................... vii

\section{Chapter I}

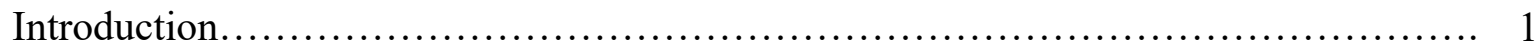

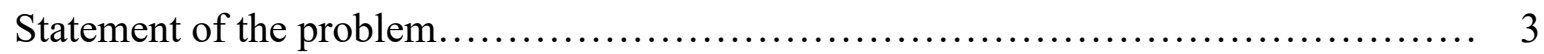

Significance of the study .................................................. 3

Null hypothesis............................................................ 3

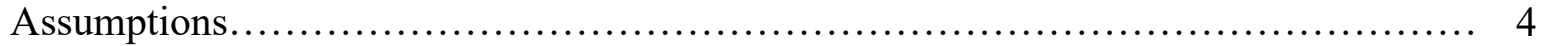

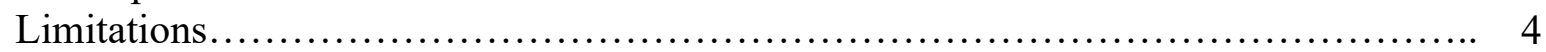

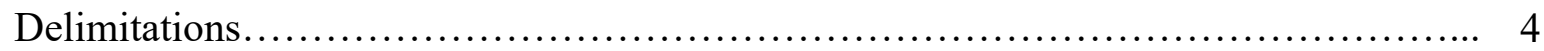

\section{Chapter II}

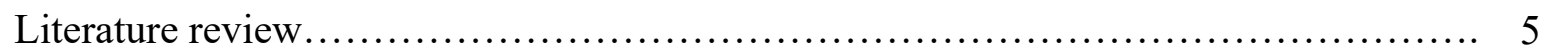

\section{Chapter III}

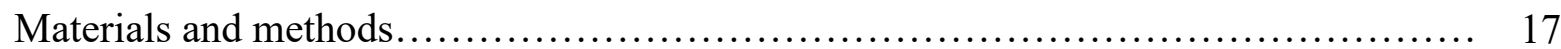

\section{Chapter IV}

Results..................................................................... 19

Discussion............................................................ 30

\section{Chapter V}

Conclusion................................................................... 33

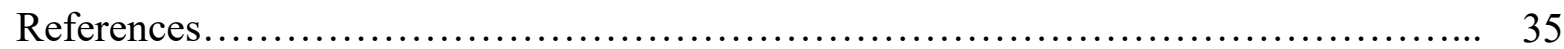

\section{Appendix}

Tables 1-21 


\section{List of Tables}

Table 1 - Most recommended analgesic

Table 2 - Most recommended antibiotic

Table 3 - Most common supplemental anesthesia for irreversible pulpitis

Table 4 - Routine CBCT use for emergency treatments

Table 5 - Microscope use for emergency treatments

Table 6 - Length of time between treatments

Table 7 - Level of pulp removal on irreversible pulpitis with normal apical tissues

Table 8 - Level of pulp removal on irreversible pulpitis with acute apical periodontitis

Table 9 - Level of pulp removal on necrotic pulp with apical periodontitis, no swelling

Table 10 - Level of pulp removal on necrotic pulp with fluctuant swelling, no drainage

Table 11 - Level of pulp removal on necrotic pulp with fluctuant swelling, with drainage

Table 12 - Level of pulp removal on necrotic pulp with diffuse facial swelling, no drainage

Table 13 - Level of pulp removal on necrotic pulp with diffuse facial swelling, drainage through canal

Table 14 - Level of instrumentation on irreversible pulpitis with normal apical tissues

Table 15 - Level of instrumentation on irreversible pulpitis with acute apical periodontitis

Table 16 - Level of instrumentation on necrotic pulp with acute apical periodontitis, no swelling

Table 17 - Level of instrumentation on necrotic pulp with fluctuant swelling and drainage

Table 18 - Level of instrumentation on necrotic pulp with fluctuant swelling, no drainage

Table 19 - Level of instrumentation on necrotic pulp with diffuse facial swelling, drainage through canal

Table 20 - Level of instrumentation on necrotic pulp with diffuse facial swelling, no drainage Table 21 - Adjunct treatment modalities 


\section{List of Symbols, Abbreviations, or Nomenclature}

American Association of Endodontists - AAE

Cone beam computed tomography - CBCT

Electronic Apex Locator - EAL

Incision and drainage - I\&D

Inferior alveolar nerve block - IANB

Mesio-buccal canals - MB1; MB2

Nonsteroidal anti-inflammatory drugs - NSAIDs

Nonsurgical root canal therapy - NSRCT

Periapical radiographs - PAs

Periodontal ligament - PDL

Radiographic - R 


\section{Chapter I}

\section{Introduction}

Endodontic emergencies often arise in many different forms such as constant throbbing pain, swelling, spontaneous pain, cracked tooth, sensitivity to thermal changes, etc. An endodontic emergency is technically defined as pain and/or swelling associated with various stages of an inflammatory reaction or infection from pulpal and/or periapical tissues (1). The diagnosis of the level of inflammation and treatment should be based on symptoms and vitality testing. However, due to evolving treatment guidelines, clinical expertise and experience, philosophies in differing practices, level and location of education, and other factors, the treatment for endodontic emergencies vary from practice to practice. To examine these differences, similar surveys were provided to certified endodontists in 1977, 1990, and 2009. Questions on the survey included how the endodontist would assess the following clinical presentations: Irreversible pulpitis or necrotic pulp with a combination of normal apical tissues, acute apical periodontitis, fluctuant swelling, diffuse swelling, and draining through an abscess versus the tooth. These surveys also explored the level of instrumentation, intracanal medicament use, analgesic and antibiotic use, and other various adjunct treatments $(2,3,4,5)$.

Since these surveys have been conducted, clinical modality of treatment has changed due to new materials, new irrigation techniques, and new evidence-based research which supports clinical success of outcomes. For instance, the accuracy of electronic apex locators has shifted the practice of finding the working length from the radiographic apex to a specific reading on the apex locator (6). Several decades ago, it was an uncommon practice to be completing a root canal treatment in a single appointment, despite the findings in early clinical trials. In the last decade itself, not only have single visit appointments been studied in research and proved to be 
clinically successful, but it has also become the treatment of choice for many endodontists. The higher concentration of sodium hypochlorite and methods of sonic/ultrasonic irrigation have contributed to faster dissolving times while maintaining appropriately disinfected canals possibly negating the need for calcium hydroxide in every case. Although still practiced by some endodontists, leaving the tooth open and trephination are treatment modalities that were once popular but have been found to be unnecessary due to new clinical protocols and the help of modern medicine contributing to more appropriate antibiotic use (5). In addition, the technological advancements of cone beam computed technology and microscope use have helped determine the extent of various lesions and swellings and can also impact the treatment. Finally, the COVID-19 pandemic has influenced dental care and the management of dental emergencies in ways that were not anticipated for the provision of dental care for endodontic emergencies. There is the potential for greater antibiotic use and the postponement of some care as a result.

The purpose of this study is to assess the current trends of treatment by endodontists in a given endodontic emergency situation. Furthermore, this study will compare the responses between board certified, non-board certified, and resident endodontists to assess differences of treatment and procedures based on the level of education. This survey can serve as an educational tool for practitioners at all levels performing root canal therapy to become knowledgeable on current research trends and clinical practices to provide the best care for our patients. 


\section{Statement of the Problem}

It is important to determine the current trends in managing endodontic emergencies in the U.S. considering changes in treatment modalities and technological advancements.

In previous studies of endodontic treatment trends, researchers examined the responses of only the diplomates of the American Board of Endodontists. These diplomates were individuals who reached the highest level of education in endodontics by partaking in a series of oral and written examinations, in addition to submitting a case portfolio. These examinations are based on extensive research background including classic and current literature. These previous surveys did not include non-certified or resident endodontists. On the other hand, most endodontic residencies participate in weekly current literature sessions of evidence-based research. In an environment where residents are constantly learning new techniques, they are able to implement new skills based on current literature in a more adaptable setting.

\section{Significance of the Study}

The significance of this study is to evaluate the current trends in endodontic emergency treatments. The researcher will also explore the treatment options based on level of education board certified, non-board certified, and resident status.

\section{Hypothesis}

- Null hypothesis $\mathrm{H}_{\mathrm{o}}$ : There is no difference in the mean response of board certified, nonboard certified, and resident status on the current trends in the management of endodontic emergencies. 
- Alternate hypothesis $\mathrm{H}_{\mathrm{a}}$ : There is a difference in the mean response of board certified, non-board certified, and resident status on the current trends in the management of endodontic emergencies.

\section{Assumptions}

- Current trends in the management of endodontic emergencies have changed in some various ways in the last 10 years (more inclination toward root canal completion in single versus multiple appointments, preference of apex locator over radiographic apex for working length measurement, changes in analgesic and antibiotic use).

- Current trends in the management of endodontic emergencies do significantly change based on level of education between board certified, non-board certified, and resident endodontists.

\section{Limitations}

- Number of respondents may be limited due to low response rate

- Only resource is the database from the American Association of Endodontics in which the participant must be an active member

- American Board of Endodontics was unable to provide database of diplomates

- Self-report has limitations in terms of validity and reliability

\section{Delimitations}

- Individuals participating are specialists in the field of endodontics

- Individuals participating are given the same survey and subset of questions 


\section{CHAPTER II}

\section{Literature Review}

\section{Diagnosis}

\section{Level of Instrumentation}

\section{Single vs. Multiple Visit}

\section{Analgesics and Antibiotics}

\section{Supplemental Anesthesia}

\section{Adjunctive Treatments}

\section{CBCT and Microscope Use}

\section{Diagnosis}

Prior to treating an endodontic emergency, it is necessary to obtain the patient's chief complaint, medical history, clinical and radiographic examination (periapical, bitewing, cone beam computed tomography), and perform vitality testing to determine the pulpal and periapical status. Clinical examination should also specify the intensity and duration of pain, and to assess fluctuant versus diffuse swelling as this can change the mode of treatment. Regarding pulpal status, vital teeth can be presented as such;

- Normal - the teeth are asymptomatic with no objective pathosis

- Reversible pulpitis - there is reversible sensitivity to cold and/or osmotic changes (sweet, salty, sour)

- Irreversible pulpitis - the sensitivity to temperature changes is more intense and with a longer duration, and pain can be spontaneous 
Reversible pulpitis is often triggered by exposed dentin, carious lesion, recent dental treatment, defective or leaking restorations. Irreversible pulpitis can be categorized further into symptomatic and asymptomatic. Asymptomatic irreversible pulpitis refers to a tooth which does not display symptoms of thermal sensitivity and may or may not exhibit pain on percussion/palpation. Symptomatic irreversible pulpitis however displays the above symptoms of lingering pain, sharp, intense pain to thermal sensitivity, referred pain, spontaneous pain and is considered an endodontic emergency that requires immediate treatment (1).

Pulp necrosis is a clinical diagnosis indicating the death of the dental pulp, which may require root canal treatment. This tooth would not be responsive to vitality testing and can present as asymptomatic. A diagnosis of necrotic pulp would need to be differentiated from a tooth that is calcified or had trauma. Although a necrotic tooth may not exhibit symptoms of pulpal inflammation, it can still harbor an infection which can travel to the periapical region and necessitate emergency endodontic treatment (7).

Periapical diagnoses include

- Normal apical tissues

- Symptomatic apical periodontitis

- Asymptomatic apical periodontitis

- Chronic apical abscess

- Acute apical abscess

Normal apical tissues are not sensitive to percussion or palpation and are considered an adequate baseline for the problem tooth. Symptomatic apical periodontitis indicates inflammation of the apical periodontium which produces clinical symptoms to painful 
response on percussion, palpation, and biting. This tooth may or may not show radiographic changes. Asymptomatic apical periodontitis does appear as an apical radiolucency, however it does not exhibit any clinical symptoms like pain to percussion or palpation. Chronic apical abscess is described as a gradual onset of inflammation and destruction of the apical periodontium by pulpal infection and necrosis, little or no discomfort, and occasional discharge of pus through an accompanying sinus tract. Osseous destruction around the root may be seen as a radiolucency. It is important to trace the sinus tract with gutta percha and obtain a radiograph to identify the source of the draining sinus tract. Acute apical abscess is characterized by a rapid onset, spontaneous pain, extreme tenderness from tooth pressure, swelling and purulent formation of neighboring tissues. There may not be radiographic change, however the patient will often experience malaise, lymphadenopathy, and fever - all which necessitate emergency treatment (7).

\section{Level of Instrumentation}

Emergency management of a tooth needing more than just an occlusal adjustment can be dependent on time limitations and clinical ability of the endodontist. The first line of procedural interventions for emergency treatment includes pulpotomies and pulpectomies. The goal of reducing pain includes pulpal debridement, with the intent of finishing the procedure through complete instrumentation. However, total pulp removal and cleaning of the root canal system may not be feasible. Both treatment options have greater than $90 \%$ success rate in predictably reducing postoperative pain from moderate to severe to mild to no pain (8). 
Some practitioners believe these teeth should be treated with a pulpotomy, where only the inflamed tissue in the coronal pulp chamber is removed. Effective pulpotomies can be accomplished in symptomatic irreversible pulpitis cases with adequate removal of the inflamed pulp tissue, preferably at the level of canal orifice. These should be followed by an adequate orifice barrier and coronal seal to prevent bacterial penetration between appointments if definitive root canal therapy is still indicated (9).

Both vital and especially necrotic pulps can benefit from pulpectomy procedures. However, an issue that can arise due to lack of instrumentation is a partial pulpectomy and should be avoided for the following reasons:

- Sensory nerve sprouting from random peripheral axotomy;

- Residual inflamed tissue as a source of pain;

- Residual necrotic tissue that precludes adequate chemo-mechanical debridement.

Due to these reasons, Lee and associates (2009) surveyed AAE members for irreversible and necrotic cases and found statistical significance with complete instrumentation regardless of the type of swelling (fluctuant versus diffuse) and chose not to leave the tooth open. They also reported placement of an intracanal medicament being the preferred choice among most endodontists at that time (5), with the most common intracanal medicament being calcium hydroxide due to its bactericidal and detoxification effect (10).

Regarding level of instrumentation, working length determination can be found depending on radiographic versus electronic apex locator readings. Before the invention of electronic apex locators, it was common practice to use a periapical radiograph to determine the working length. However, after electronic apex locators have been developed, it has been 
proven that the working length can be found in a more precise manner without over-exposing the patient to radiation (6).

\section{Single versus Multiple Visit}

Although calcium hydroxide is one of the most common intracanal medicaments, more evidence is emerging that questions the effectiveness of calcium hydroxide against several microorganisms commonly associated with persistent apical periodontitis (11). While some have found improved healing with using calcium hydroxide in multiple appointments (12), others have observed little or no benefit (13). There is also a question of completing a root canal to the standard of care in a single visit appointment compared to the conventional multiple visit appointments (14). Beginning 1978, Soltanoff and Montclair studied teeth endodontically treated in either a single visit or in multiple visits over the course of 20 years. They surveyed patients on post-operative pain and healing capabilities between the two treatment options. They found that while there was statistically significant post-operative pain associated with single visit compared the multiple visit, both treatment modalities had equal healing (14).

Over the last few decades, many researchers are arguing no significant differences in antimicrobial efficacies between single versus multiple visits (13-16). The invention of rotary nickel-titanium systems and improvements in irrigation dynamics have helped to streamline mechanical instrumentation and disinfection of the root canal, providing single-appointment treatment as a more convenient option. In a systematic review studying healing rate and postobturation pain of single versus multiple visit endodontic treatment for infected root canals, Su et al., (2011) found no significant difference in healing rates, no significant difference in 
the incidence of medium term (7-10 days) post-obturation pain, and significantly lower postobturation pain in a short term (within 3 days) follow up with single visit compared to multiple visit (15). Another systematic review by Moreira et al., (2017) showed similar success rates between single and multiple visit regardless of precondition of pulp and periapex, and decreased incidence of post-operative complications and higher efficiency in single visit appointments (16).

In the event of a necrotic case, the most common treatment option was/still is to complete treatment in multiple visits in order to control the microbial load. Aside from calcium hydroxide, in the last two decades, chlorohexidine has received attention as an intracanal irrigant and intra-appointment medicament. In a randomized control trial done by Penesis et al., (2008) they studied healing of necrotic teeth with apical periodontitis with endodontic treatment at one year between single visit and multiple visits. The intracanal medicament used in this study was a paste dressing made from a combination of calcium hydroxide and chlorohexidine. The results of this study showed equally favorable periapical healing at 12 months, with no statistically significant differences between the single versus multiple visit groups (17). With advantages in reduced clinical time, cost effectiveness, better patient acceptance, and proposed reduction of interappointment infection risks, single visit root canal treatment has become a more acceptable approach compared to traditional multiple visit root canal therapy.

\section{Analgesics and Antibiotics}

Aside from the pain experienced by patients in a pre-operative setting, the completion of 
a root canal treatment may also necessitate the need for medication to help alleviate the discomfort. There have been several pharmacological modalities for the treatment of postendodontic pain including nonsteroidal anti-inflammatory drugs (NSAIDs), acetaminophen, corticosteroids, and opioids. NSAIDs are the most common medication used for managing pain post-treatment. However, due to medical limitations, NSAIDs may not be readily available. Acetaminophen, whether alone or in combination with an opioid, is often used as an alternative medication for patients who cannot tolerate NSAIDs. However, there are risks associated with acetaminophen for liver damage and a reaction in patients taking asthma medication. Additionally, the risk with opioids lies with the conflict of over-prescribing during an opioid epidemic.

Multiple studies have advocated the use of a combined administration of ibuprofen and acetaminophen in patients who can tolerate both classes of drugs (18). Simultaneous administration of ibuprofen and acetaminophen can produce greater peak and more consistent analgesia without increase side effects (18). A systematic review and network meta-analysis by Zanjir et al., (2020) compared placebo, NSAIDs, alone and in combination with acetaminophen and other medications (opioids, corticosteroids, benzodiazepines) and found either NSAIDs alone or in combination with acetaminophen after root canal therapy resulted in a decrease in postoperative pain for patients with irreversible pulpitis or pulpal necrosis compared to other medications (19). Interestingly, in a study by Mickel et al., (2006) a survey for members of the American Association of Endodontists (AAE) on various choices for analgesic prescriptions, found non-narcotics were preferred over narcotics for all clinical situations however, educators and board-certified AAE members were less likely 
than non-board certified AAE members to manage patient's severe pain with narcotic analgesics (20).

Because odontogenic infections are polymicrobial, it is important to eliminate the source of infection through pulpectomy, incision and drainage, or local debridement. Antibiotics are seen only as an adjunct therapy in the management of periradicular infections. In 2016 the Centers for Disease Control and Prevention (CDC) reported nearly 26 million oral systemic antibiotic prescriptions were written by dentists alone (21). In an effort to reduce overprescribing antibiotics, it is important to consider the true indications for adjunctive antibiotics. The American Association of Endodontics in 2019 published in the Colleagues of Excellence report the indications for adjunctive antibiotics which include: acute apical abscess in immunocompromised patients (localized fluctuant swellings, systemic disease causing impaired immunologic function), acute apical abscess with systemic involvement (body temperature $>100$ degrees Fahrenheit, malaise, unexplained trismus, lymphadenopathy), progressive infections (rapid onset of swelling $<24$ hours, cellulitis or a spreading infection, osteomyelitis), persistent infection (chronic exudation). Adjunctive antibiotics are not recommended in symptomatic irreversible pulpitis, symptomatic apical periodontitis, teeth with necrotic pulp and a radiolucency, teeth with a sinus tract or parulis, acute apical abscess in immunocompetent patients (22).

In the event a prescription is necessary, endodontists should use the shortest effective course of a narrow-spectrum antibiotic (23). The first line of therapeutic antibiotics are amoxicillin and penicillin vk, in patients without a penicillin allergy. If a patient continues to have an unresolved or recalcitrant infection after being treated with penicillin vk, then a combination of amoxicillin with clavulanic acid should be used, however sparingly as it can 
cause gastrointestinal and hepatic adverse effects (24). For patients with a penicillin allergy, the antibiotic of choice used to be clindamycin; however due to the risk of fatal colitis and black box warning for diarrhea associated with clostridium difficile, the newly recommended alternative is azithromycin (22).

\section{Supplemental Anesthesia}

One of the most difficult aspects of an emergency treatment, especially in the case of a symptomatic irreversible pulpitis, is getting the tooth anesthetized prior to accessing the nerve. Some studies have reported that patients with severe pain are eight times more likely than normal controls to have local anesthetic failure after administering the inferior alveolar nerve block injection (IANB) on mandibular posterior teeth (25). When situations like this occur, there are various supplemental anesthesia techniques that can be used to create profound anesthesia in a very symptomatic tooth. These options include a repeat inferior alveolar nerve block, buccal infiltration, periodontal ligament injection (intraligamentary), intraosseous injection, and intrapulpal injection.

In 1992, Walton and Torabinejad recommended using periodontal ligament (PDL) and intrapulpal injections if profound anesthesia did not occur with standard IANB injection (26). In a study done by Kanaa et al., (2012) different supplementary injections were used on patients with irreversible pulpitis in mandibular teeth, after the failure of an IANB injection. They found supplemental buccal infiltration with $4 \%$ articaine with epinephrine and intraosseous injection with $2 \%$ lidocaine with epinephrine are more likely to create pain-free treatment compared to periodontal ligament and repeat IANB injections (27). However, in a study by Fowler et al., (2016) the results indicated low success rates for the IANB with 
supplemental buccal infiltration with articaine in symptomatic irreversible molars to ensure profound pulpal anesthesia (28). With changes in anesthesia techniques, even with all these different supplementary options available, studies vary in their outcomes leaving practitioners to find a method that predictably works in their hands.

\section{Adjunctive Treatments}

Adjunctive therapies to root canal treatments help to reduce the inflammatory process which is the underlying reason for most acute dental pain emergencies. A study done by Rosenberg et al., (1998) showed occlusal reduction significantly reduced pain in patients with vital pulps, periradicular symptoms and pre-operative pain, 48 hours post instrumentation (29). Another adjunctive therapy is trephination - cutting a piece of bone to relieve pressure. Henry et al., (2003) presented a case report study in which surgical trephination was used to drain an infection and provide immediate relief of pain for managing patients with acute pain (30). However a study by Nist et al., (2001) the trephination procedure did not cause significant reduction in post operative pain, percussion pain, or swelling (31).

In hopes to facilitate a quicker recovery and reduce the need for antibiotics, the AAE recommends the management of soft tissue edema of odontogenic origin include incision and drainage (I\&D). A sharp incision is made through the oral mucosa which extends to the alveolar bone to help rid the tissues of toxic purulent material and decompress the tissues. This procedure allows increased oxygenation to the infected area with better perfusion of blood to heal tissues in a more time efficient manner. Aside from fluctuant swelling, if the swelling is increasing in size or has progressed into cellulitis, antibiotics can be prescribed in 
addition to I\&D (22). Drainage from the canal after initiating treatment can also help reduce discomfort and pain (32). However a recent study by Beus et al., (2018) found that in patients with clinical swelling, the group who received mock I\&D procedure with mock drain placement had more success than patients who received I\&D with drain placement, with both groups having an equal decrease in postoperative pain (33).

In 1977, a survey to board certified endodontists reported that if swelling was present, the majority of respondents would leave the tooth open and instrument past the apex to facilitate drainage through the canals. About $25.2 \%$ to $38.5 \%$ of the clinicians, in the event of diffuse swelling would leave the tooth open. Roughly $17.5 \%$ to $31.5 \%$ left the teeth open in the presence of a fluctuant swelling $(2,4)$. Current research has shown however that leaving the tooth open can introduce new bacteria into a current infection, allowing necrotic debris to be pushed beyond the apex and can result in posttreatment discomfort and longer healing time (34).

\section{CBCT and Microscope Use}

Regardless of any endodontic emergency, the preferred method for endodontists includes the use of a microscope and, more recently, accessibility to a cone beam computed tomography device (CBCT). Stropko (1999) treated about 1,700 maxillary molars with a microscope and without aided vision. The incidence of locating second mesio-buccal canals (MB2) increased from $73.2 \%$ to $93.0 \%$ in first molars and $50.7 \%$ to $60.4 \%$ in second molars (35). Monea et al., (2015) showed improved treatment outcomes, measured in decreased or disappeared radiolucency after performing a root canal treatment with a microscope compared to without (36). Regarding fractured teeth in endodontic emergencies, the ability to 
recognize a fracture with a microscope comes more easily than with standard loupes. Having this capability can determine if the prognosis of the treatment will decrease depending on the extent of the fracture, which may necessitate an extraction instead of root canal therapy.

Although traditional two-dimensional radiographs, periapical (PA) and bitewing (BW), continue to be the most popular type of imaging, the diagnostic potential is limited. When evaluating healing of periapical lesions using 2-D PAs, the agreement between six examiners was only $47 \%$. When the same films were read at a later time, only $19-80 \%$ had agreement with their previous interpretations (37). Other clinical studies have shown the ability of detecting a periapical radiolucency on a PA film was $20 \%$ compared to $48 \%$ when using CBCT (38). In situations where a vertical root fracture emergency can mimic symptoms of symptomatic irreversible pulpitis with symptomatic apical periodontitis, unnecessary root canal treatment can mistakenly be performed. A comparative study was done to assess sensitivity and specificity of CBCT and PAs in detecting vertical root fractures. The sensitivity and specificity were $79.4 \%$ and $92.5 \%$ respectively for CBCT and $37.1 \%$ and $95 \%$ respectively for PAs (39). Other endodontic emergencies that have improved diagnoses with CBCT are detection of inflammatory resorptive defects and traumatic dental injuries such as luxations, horizontal root fracture, and avulsions. CBCT provides more information for treatment planning and management of endodontic problems.

It is important to determine the current trends in managing endodontic emergencies in the U.S. as, significant changes in treatment modalities have changed along with clinical and technological advancements. Therefore, this research was important to undertake to determine these practices. 


\section{CHAPTER III}

\section{Materials and Methods}

\section{Ethical Statement}

This research was approved by the West Virginia University Institutional Review Board (WVU protocol \#2010152052).

\section{Study Design}

An observational, cross-sectional study design was used for a descriptive analysis of current practices among endodontists. A survey, based upon two previous surveys of endodontists and expert advice was created. The survey was placed into the West Virginia University REDCap electronic data capture tools. (40, 41). REDCap (Research Electronic Data Capture) is a secure, web platform for creating and managing online databases and surveys which can be virtually collected and applied to various statistical software programs $(40,41)$.

\section{Survey}

Surveys were emailed to 3,157 active members of the American Association of Endodontists via link through REDCap services. 394 members of the American Association of Endodontists completed the survey which is about a $12.5 \%$ response rate. Data were collected from March to June 2021. Past surveys included only Diplomates of the American Board of Endodontics however when asked for this database, new policies do not allow disclosure of members' names and emails. It was then decided to include members of the AAE, which allowed representation of board certified, non-board certified, and resident members. 
There was no compensation for participating in this survey and refusal to participate in this study did not affect the respondents in any way. There was no conflict of interest associated with this research. The questionnaire was predicted to take approximately 10 minutes for completion and consisted of multiple choice and select all that apply questions as well as a free response section at the end of the survey for additional comments. Questions on different topics were included in the survey: current status though the American Board of Endodontics, number of years in practice, academics versus practitioner status, region of practice in the United States, length of time between emergency and definitive treatment, commonly prescribed analgesics and antibiotics, supplemental anesthesia technique, and the use of $\mathrm{CBCT}$ and microscope. Questions pertaining to treatment modalities for specific diagnoses included: level of pulp removal, method of obtaining working length, completing NSRCT in one versus multiple visits, and other adjunct therapy techniques.

\section{Data Analysis}

All statistical analysis was performed using SPSS statistics software, version 27 (IBM Corp, Armonk, NY). Data was analyzed using cross tabulation and Pearson chi-square analysis to compare mean responses of three groups - board certified, non-board certified, and residents on current trends in the management of endodontic emergencies. A p-value of less than 0.05 was considered statistically significant. 


\section{CHAPTER IV}

\section{Results}

There were 394 responses (12.5\% response rate). Of these respondents, $41.4 \%$ are board certified, $46.2 \%$ are non-board certified, and $12.4 \%$ are of resident status. Regarding number of years practiced as an endodontist, the results are as followed: $52.6 \%$ practiced $16-40$ years, 29.7\% practiced 6-15 years, and 17.6\% practiced less than 6 years. Most respondents identified as full-time private practitioners $(88.9 \%)$, followed by part time private practitioner $(8.8 \%)$, full time faculty members $(1.3 \%)$, part time faculty members $(8.3 \%)$, and retired $(1.0 \%)$. The area in which the respondents reside in are as follows:

- $24.6 \%$ were from the West (WA, OR, CA, ID, NV, UT, AZ, AK, HI)

- $18.5 \%$ from Southeast (KY, TN, AR, LA, MS, AL, GA, FL)

- $\quad 17.3 \%$ from Midwest (NM, CO, WY, MT, ND, SD, NE, KS, OK, TX, IA, MO)

- $\quad 16.5 \%$ Great Lakes (MN, WI, IL, IN, MI, OH)

- $\quad$ 13.2\% Mid Atlantic (PA, MD, DE, WV, VA, NC, SC, Washington DC)

- $\quad 9.9 \%$ from Northeast (MA, RI, CT, VT, NH, ME, NY, NJ).

Practitioners were asked to identify all the analgesics routinely prescribed or recommended. Results are presented on Table 1 below. The most prescribed/recommended medication was ibuprofen at $99.2 \%$. There were $66.4 \%$ who prescribed/recommended acetaminophen, 10.6\% who prescribed/recommended Vicodin, 10.4\% who prescribed/recommended other medications not listed, 9.1\% who prescribed Tylenol 3, 2.8\% who prescribed Percocet, and 1.8\% who prescribed Lortab. 
TABLE 1. Most recommended analgesic

Response Percent

\begin{tabular}{ll}
\hline Ibuprofen & $99.2 \%$ \\
Acetaminophen & $66.4 \%$ \\
Vicodin & $10.6 \%$ \\
Other & $10.4 \%$ \\
Tylenol \#3 & $9.1 \%$ \\
Percocet & $2.8 \%$ \\
Lortab & $1.8 \%$
\end{tabular}

Note: multiple choices were permitted

A similar question was posted about antibiotics. Results are presented in Table 2. There were $88.3 \%$ who prescribed amoxicillin, $65.1 \%$ who prescribed clindamycin, $31.8 \%$ who prescribed augmentin, $24.4 \%$ who prescribed penicillin, $13.2 \%$ who prescribed medications other than those listed, $11.2 \%$ who prescribed Metronidazole, $7.4 \%$ who prescribed Cephalexin, and 1.3\% who prescribed Erythromycin.

TABLE 2. Most recommended antibiotic

\begin{tabular}{ll}
\hline & Response Percent \\
\hline Amoxicillin & $88.3 \%$ \\
Clindamycin & $65.1 \%$ \\
Augmentin & $31.8 \%$ \\
Penicillin & $24.4 \%$ \\
Other & $13.2 \%$ \\
Metronidazole & $11.2 \%$ \\
Cephalexin & $7.4 \%$ \\
Erythromycin & $1.3 \%$ \\
\hline
\end{tabular}

Note: multiple choices were permitted

Participants were asked about the most common supplemental anesthesia for irreversible pulpitis. Results are presented in Table 3 . There were $33.5 \%$ of board certified endodontists who selected both articaine infiltration and periodontal ligament injection equally. There 
were $37.7 \%$ of non-board certified endodontists who selected periodontal ligament injection, and $35.6 \%$ of residents selected periodontal ligament injections, however these results were not statistically significant $\left(\chi^{2}=14.083 ; P=0.08\right)$.

TABLE 3. Most common supplemental anesthesia for irreversible pulpitis

\begin{tabular}{|c|c|c|c|c|c|c|}
\hline & $\begin{array}{c}\text { Articaine } \\
\text { infiltration }\end{array}$ & $\begin{array}{c}\text { Intraosseous } \\
\text { injection }\end{array}$ & $\begin{array}{c}\text { Intrapulpal } \\
\text { injection }\end{array}$ & $\begin{array}{c}\text { Periodontal } \\
\text { ligament } \\
\text { injection }\end{array}$ & None & Total \\
\hline $\begin{array}{c}\text { Board } \\
\text { certified }\end{array}$ & $33.5 \%$ & $23.8 \%$ & $9.1 \%$ & $33.5 \%$ & $0 \%$ & $100 \%$ \\
\hline $\begin{array}{c}\text { Non-board } \\
\text { certified }\end{array}$ & $31.7 \%$ & $16.4 \%$ & $14.2 \%$ & $37.7 \%$ & $0 \%$ & $100 \%$ \\
\hline Resident & $24.5 \%$ & $20.4 \%$ & $18.4 \%$ & $34.7 \%$ & $2.0 \%$ & $100 \%$ \\
\hline Average & $31.6 \%$ & $19.9 \%$ & $12.6 \%$ & $35.6 \%$ & $0.3 \%$ & $100 \%$ \\
\hline
\end{tabular}

Participants were asked about routine CBCT use for emergency treatments. Results are shown in Table 4 . There were $47.6 \%$ of board certified endodontists who selected Yes, $30.1 \%$ of non-board certified endodontists selected No, and $20.4 \%$ of residents selected No. This data was considered statistically significant $\left(\chi^{2}=25.477 ; P=0.00\right)$.

TABLE 4. Routine CBCT use for emergency treatments

\begin{tabular}{|c|c|c|c|c|}
\hline & Yes & No & Occasionally & Total \\
\hline Board certified & $47.6 \%$ & $22.6 \%$ & $29.9 \%$ & $100 \%$ \\
\hline $\begin{array}{c}\text { Non-board } \\
\text { certified }\end{array}$ & $30.1 \%$ & $44.3 \%$ & $25.7 \%$ & $100 \%$ \\
\hline Resident & $20.4 \%$ & $42.9 \%$ & $36.7 \%$ & $100 \%$ \\
\hline Average & $36.1 \%$ & $35.1 \%$ & $28.8 \%$ & $100 \%$ \\
\hline
\end{tabular}


Considering microscope use during emergency treatments, board certified endodontists were more likely than non-board certified endodontists or residents to always use a microscope $\left(\chi^{2}=20.377 ; P=0.003\right)$. For the "Always" category, there were $82.3 \%$ board certified endodontists, $73.8 \%$ non-board certified endodontists, and $55.1 \%$ of residents who always used the microscope for emergencies.

TABLE 5. Microscope use for emergency treatments

\begin{tabular}{|c|c|c|c|c|c|}
\hline & $\begin{array}{c}\text { Up to } 50 \% \\
\text { of time }\end{array}$ & $\begin{array}{c}50-75 \% \text { of } \\
\text { time }\end{array}$ & $\begin{array}{c}\text { Greater than } \\
75 \% \text { of time }\end{array}$ & Always & Total \\
\hline $\begin{array}{c}\text { Board } \\
\text { certified }\end{array}$ & $6.7 \%$ & $2.4 \%$ & $8.5 \%$ & $82.3 \%$ & $100 \%$ \\
\hline $\begin{array}{c}\text { Non-board } \\
\text { certified }\end{array}$ & $13.3 \%$ & $3.3 \%$ & $9.8 \%$ & $73.8 \%$ & $100 \%$ \\
\hline Resident & $18.4 \%$ & $12.2 \%$ & $14.3 \%$ & $55.1 \%$ & $100 \%$ \\
\hline Average & $11.2 \%$ & $4.0 \%$ & $9.8 \%$ & $75.0 \%$ & $100 \%$ \\
\hline
\end{tabular}

Practitioners were asked about the length of time between initial emergency treatment and completion of root canal therapy. The results are shown in Table 6. Participants at all levels of education had similar choices for time between treatment. For the 1-2 week choice, $43.2 \%$ of board certified endodontists selected; $32.8 \%$ of non-board certified selected it; and $40.8 \%$ of residents selected it. However, the results were not statistically significant $\left(\chi^{2}=6.060 ; P=0.646\right)$. 
TABLE 6. Length of Time Between Treatment

\begin{tabular}{|c|c|c|c|c|c|c|}
\hline & $\begin{array}{c}\text { Less than 1 } \\
\text { week }\end{array}$ & $1-2$ weeks & $2-3$ weeks & $\begin{array}{c}\text { More than 3 } \\
\text { weeks }\end{array}$ & $\begin{array}{c}\text { Treatment } \\
\text { completed 1 } \\
\text { visit }\end{array}$ & Total \\
\hline $\begin{array}{c}\text { Board } \\
\text { certified }\end{array}$ & $11.1 \%$ & $43.2 \%$ & $16.0 \%$ & $2.5 \%$ & $27.2 \%$ & $100 \%$ \\
\hline $\begin{array}{c}\text { Non-board } \\
\text { certified }\end{array}$ & $16.7 \%$ & $32.2 \%$ & $16.7 \%$ & $1.7 \%$ & $32.8 \%$ & $100 \%$ \\
\hline Resident & $14.3 \%$ & $40.8 \%$ & $14.3 \%$ & $2.0 \%$ & $28.6 \%$ & $100 \%$ \\
\hline Average & $14.1 \%$ & $37.9 \%$ & $16.1 \%$ & $2.0 \%$ & $29.9 \%$ & $100 \%$ \\
\hline
\end{tabular}

Members were asked about level of pulp removal (partial pulpotomy, complete pulpotomy, pulpectomy, complete instrumentation). The result are shown in Tables 7-13. The majority of responses from board certified, non-board certified, and residents was complete instrumentation for all 7 diagnoses. However, the results were not statistically significant. The Pearson Chi-Square and $\mathrm{p}$ value for each diagnosis are as follows, respectively: irreversible pulpitis with normal apical tissues $\left(\chi^{2}=5.605 ; P=0.471\right)$, irreversible pulpitis with acute apical periodontitis $\left(\chi^{2}=2.726 ; P=0.859\right)$, necrotic pulp with apical periodontitis and no swelling $\left(\chi^{2}=2.142 ; P=0.726\right)$, necrotic pulp with fluctuant swelling and no drainage $\left(\chi^{2}=2.517 ; P=0.642\right)$, necrotic pulp with fluctuant swelling with drainage $\left(\chi^{2}=3.853 ; P=0.428\right)$, necrotic pulp with diffuse facial swelling and no drainage $\left(\chi^{2}\right.$ $=4.873 ; P=0.292$ ), and necrotic pulp with diffuse facial swelling with drainage through canal $\left(\chi^{2}=5.942 ; P=0.203,5.942\right)$. 
TABLE 7. Level of pulp removal on irreversible pulpitis with normal apical tissues

\begin{tabular}{|c|c|c|c|c|c|}
\hline & $\begin{array}{c}\text { Partial } \\
\text { pulpotomy }\end{array}$ & $\begin{array}{c}\text { Complete } \\
\text { pulpotomy }\end{array}$ & Pulpectomy & $\begin{array}{c}\text { Complete } \\
\text { instrumentation }\end{array}$ & Total \\
\hline $\begin{array}{c}\text { Board } \\
\text { certified }\end{array}$ & $2.5 \%$ & $8.6 \%$ & $17.8 \%$ & $71.2 \%$ & $100 \%$ \\
\hline $\begin{array}{c}\text { Non-board } \\
\text { certified }\end{array}$ & $0.5 \%$ & $5.5 \%$ & $20.8 \%$ & $73.2 \%$ & $100 \%$ \\
\hline Resident & $0.0 \%$ & $8.2 \%$ & $24.5 \%$ & $67.3 \%$ & $100 \%$ \\
\hline Average & $1.3 \%$ & $7.1 \%$ & $20.0 \%$ & $71.6 \%$ & $100 \%$ \\
\hline
\end{tabular}

TABLE 8. Level of pulp removal on irreversible pulpitis with acute apical periodontitis

\begin{tabular}{|c|c|c|c|c|c|}
\hline & $\begin{array}{c}\text { Partial } \\
\text { pulpotomy }\end{array}$ & $\begin{array}{c}\text { Complete } \\
\text { pulpotomy }\end{array}$ & Pulpectomy & $\begin{array}{c}\text { Complete } \\
\text { instrumentation }\end{array}$ & Total \\
\hline $\begin{array}{c}\text { Board } \\
\text { certified }\end{array}$ & $0.6 \%$ & $5.5 \%$ & $17.7 \%$ & $76.2 \%$ & $100 \%$ \\
\hline $\begin{array}{c}\text { Non-board } \\
\text { certified }\end{array}$ & $0.0 \%$ & $3.4 \%$ & $20.7 \%$ & $76.0 \%$ & $100 \%$ \\
\hline Resident & $0.0 \%$ & $4.1 \%$ & $20.4 \%$ & $75.5 \%$ & $100 \%$ \\
\hline Average & $0.3 \%$ & $4.3 \%$ & $19.4 \%$ & $76.0 \%$ & $100 \%$ \\
\hline
\end{tabular}

TABLE 9. Level of pulp removal on necrotic pulp with apical periodontitis, no swelling

\begin{tabular}{|c|c|c|c|c|c|}
\hline & $\begin{array}{c}\text { Partial } \\
\text { pulpotomy }\end{array}$ & $\begin{array}{c}\text { Complete } \\
\text { pulpotomy }\end{array}$ & Pulpectomy & $\begin{array}{c}\text { Complete } \\
\text { instrumentation }\end{array}$ & Total \\
\hline $\begin{array}{c}\text { Board } \\
\text { certified }\end{array}$ & $0 \%$ & $3.1 \%$ & $14.8 \%$ & $82.1 \%$ & $100 \%$ \\
\hline $\begin{array}{c}\text { Non-board } \\
\text { certified }\end{array}$ & $0 \%$ & $1.1 \%$ & $17.7 \%$ & $81.2 \%$ & $100 \%$ \\
\hline Resident & $0 \%$ & $2.1 \%$ & $14.9 \%$ & $83.0 \%$ & $100 \%$ \\
\hline Average & $0 \%$ & $2.1 \%$ & $16.2 \%$ & $81.8 \%$ & $100 \%$ \\
\hline
\end{tabular}


TABLE 10. Level of pulp removal on necrotic pulp with fluctuant swelling, no drainage

\begin{tabular}{|c|c|c|c|c|c|}
\hline & $\begin{array}{c}\text { Partial } \\
\text { pulpotomy }\end{array}$ & $\begin{array}{c}\text { Complete } \\
\text { pulpotomy }\end{array}$ & Pulpectomy & $\begin{array}{c}\text { Complete } \\
\text { instrumentation }\end{array}$ & Total \\
\hline $\begin{array}{c}\text { Board } \\
\text { certified }\end{array}$ & $0 \%$ & $3.1 \%$ & $15.3 \%$ & $81.6 \%$ & $100 \%$ \\
\hline $\begin{array}{c}\text { Non-board } \\
\text { certified }\end{array}$ & $0 \%$ & $1.1 \%$ & $18.0 \%$ & $80.9 \%$ & $100 \%$ \\
\hline Resident & $0 \%$ & $2.1 \%$ & $21.3 \%$ & $76.6 \%$ & $100 \%$ \\
\hline Average & $0 \%$ & $2.1 \%$ & $17.3 \%$ & $80.7 \%$ & $100 \%$ \\
\hline
\end{tabular}

TABLE 11. Level of pulp removal on necrotic pulp with fluctuant swelling, with drainage

\begin{tabular}{|c|c|c|c|c|c|}
\hline & $\begin{array}{c}\text { Partial } \\
\text { pulpotomy }\end{array}$ & $\begin{array}{c}\text { Complete } \\
\text { pulpotomy }\end{array}$ & Pulpectomy & $\begin{array}{c}\text { Complete } \\
\text { instrumentation }\end{array}$ & Total \\
\hline $\begin{array}{c}\text { Board } \\
\text { certified }\end{array}$ & $0 \%$ & $3.0 \%$ & $15.9 \%$ & $81.1 \%$ & $100 \%$ \\
\hline $\begin{array}{c}\text { Non-board } \\
\text { certified }\end{array}$ & $0 \%$ & $1.1 \%$ & $19.8 \%$ & $79.1 \%$ & $100 \%$ \\
\hline Resident & $0 \%$ & $2.1 \%$ & $25.5 \%$ & $72.3 \%$ & $100 \%$ \\
\hline Average & $0 \%$ & $2.1 \%$ & $18.8 \%$ & $79.1 \%$ & $100 \%$ \\
\hline
\end{tabular}

TABLE 12. Level of pulp removal on necrotic pulp with diffuse facial swelling, no drainage

\begin{tabular}{|c|c|c|c|c|c|}
\hline & $\begin{array}{c}\text { Partial } \\
\text { pulpotomy }\end{array}$ & $\begin{array}{c}\text { Complete } \\
\text { pulpotomy }\end{array}$ & Pulpectomy & $\begin{array}{c}\text { Complete } \\
\text { instrumentation }\end{array}$ & Total \\
\hline $\begin{array}{c}\text { Board } \\
\text { certified }\end{array}$ & $0 \%$ & $3.1 \%$ & $15.4 \%$ & $81.5 \%$ & $100 \%$ \\
\hline $\begin{array}{c}\text { Non-board } \\
\text { certified }\end{array}$ & $0 \%$ & $1.1 \%$ & $21.0 \%$ & $77.8 \%$ & $100 \%$ \\
\hline Resident & $0 \%$ & $0.0 \%$ & $23.4 \%$ & $76.6 \%$ & $100 \%$ \\
\hline Average & $0 \%$ & $1.8 \%$ & $19.0 \%$ & $79.2 \%$ & $100 \%$ \\
\hline
\end{tabular}


TABLE 13. Level of pulp removal on necrotic pulp with diffuse facial swelling, drainage through canal

\begin{tabular}{|c|c|c|c|c|c|}
\hline & $\begin{array}{c}\text { Partial } \\
\text { pulpotomy }\end{array}$ & $\begin{array}{c}\text { Complete } \\
\text { pulpotomy }\end{array}$ & Pulpectomy & $\begin{array}{c}\text { Complete } \\
\text { instrumentation }\end{array}$ & Total \\
\hline $\begin{array}{c}\text { Board } \\
\text { certified }\end{array}$ & $0 \%$ & $3.1 \%$ & $17.3 \%$ & $79.6 \%$ & $100 \%$ \\
\hline $\begin{array}{c}\text { Non-board } \\
\text { certified }\end{array}$ & $0 \%$ & $1.1 \%$ & $22.5 \%$ & $76.4 \%$ & $100 \%$ \\
\hline Resident & $0 \%$ & $0.0 \%$ & $29.2 \%$ & $70.8 \%$ & $100 \%$ \\
\hline Average & $0 \%$ & $1.8 \%$ & $21.1 \%$ & $77.1 \%$ & $100 \%$ \\
\hline
\end{tabular}

The level of instrumentation (in relationship to radiographic, $\mathrm{R}$, and electronic apex locator, EAL readings) results are shown in the tables below for all 7 diagnosis scenarios in Tables 14-20. There was statistical significance for all levels of education considering instrumentation to the EAL apex with only irreversible pulpitis with acute apical periodontitis $\left(\chi^{2}=15.559 ; P=0.048\right)$. The Pearson Chi-Square and $\mathrm{p}$ values for all other diagnosis are as follows, respectively: irreversible pulpitis with normal apical tissues $\left(\chi^{2}=\right.$ $14.657 ; P=0.065)$, necrotic pulp with apical periodontitis and no swelling $\left(\chi^{2}=14.818\right.$; $P=0.061)$, necrotic pulp with fluctuant swelling and no drainage $\left(\chi^{2}=12.089 ; P=0.145\right)$, necrotic pulp with fluctuant swelling with drainage $\left(\chi^{2}=10.775 ; P=0.213\right)$, necrotic pulp with diffuse facial swelling and no drainage $\left(\chi^{2}=12.347 ; P=0.134\right)$, and necrotic pulp with diffuse facial swelling with drainage through canal $\left(\chi^{2}=11.669 ; P=0.165\right)$. 
TABLE 14. Level of instrumentation on irreversible pulpitis with normal apical tissues

\begin{tabular}{|c|c|c|c|c|c|c|}
\hline & $\begin{array}{c}0.5 \text { to } 1 \mathrm{~mm} \\
\text { short of R } \\
\text { apex }\end{array}$ & To R apex & $\begin{array}{c}\text { To EAL } \\
\text { apex }\end{array}$ & $\begin{array}{c}0.5 \text { to } 1 \mathrm{~mm} \\
\text { short of } \\
\text { EAL apex }\end{array}$ & $\begin{array}{c}\text { Past R or } \\
\text { EAL apex }\end{array}$ & Total \\
\hline $\begin{array}{c}\text { Board } \\
\text { certified }\end{array}$ & $7.9 \%$ & $0.6 \%$ & $47.0 \%$ & $40.9 \%$ & $3.7 \%$ & $100 \%$ \\
\hline $\begin{array}{c}\text { Non-board } \\
\text { certified }\end{array}$ & $10.4 \%$ & $6.0 \%$ & $48.1 \%$ & $32.8 \%$ & $2.7 \%$ & $100 \%$ \\
\hline Resident & $10.2 \%$ & $4.1 \%$ & $61.2 \%$ & $24.5 \%$ & $0.0 \%$ & $100 \%$ \\
\hline Average & $9.3 \%$ & $3.5 \%$ & $49.2 \%$ & $35.1 \%$ & $2.8 \%$ & $100 \%$ \\
\hline
\end{tabular}

TABLE 15. Level of instrumentation on irreversible pulpitis with acute apical periodontitis

\begin{tabular}{|c|c|c|c|c|c|c|}
\hline & $\begin{array}{c}0.5 \text { to } 1 \mathrm{~mm} \\
\text { short of R } \\
\text { apex }\end{array}$ & To R apex & $\begin{array}{c}\text { To EAL } \\
\text { apex }\end{array}$ & $\begin{array}{c}0.5 \text { to } 1 \mathrm{~mm} \\
\text { short of } \\
\text { EAL apex }\end{array}$ & $\begin{array}{c}\text { Past R or } \\
\text { EAL apex }\end{array}$ & Total \\
\hline $\begin{array}{c}\text { Board } \\
\text { certified }\end{array}$ & $6.7 \%$ & $1.2 \%$ & $46.6 \%$ & $42.3 \%$ & $3.1 \%$ & $100 \%$ \\
\hline $\begin{array}{c}\text { Non-board } \\
\text { certified }\end{array}$ & $9.3 \%$ & $7.1 \%$ & $49.2 \%$ & $31.1 \%$ & $3.3 \%$ & $100 \%$ \\
\hline Resident & $8.2 \%$ & $6.1 \%$ & $61.2 \%$ & $24.5 \%$ & $0.0 \%$ & $100 \%$ \\
\hline Average & $8.1 \%$ & $4.6 \%$ & $49.6 \%$ & $34.9 \%$ & $2.8 \%$ & $100 \%$ \\
\hline
\end{tabular}

TABLE 16. Level of instrumentation on necrotic pulp with acute apical periodontitis, no swelling

\begin{tabular}{|c|c|c|c|c|c|c|}
\hline & $\begin{array}{c}0.5 \text { to } 1 \mathrm{~mm} \\
\text { short of R } \\
\text { apex }\end{array}$ & To R apex & $\begin{array}{c}\text { To EAL } \\
\text { apex }\end{array}$ & $\begin{array}{c}0.5 \text { to } 1 \mathrm{~mm} \\
\text { short of } \\
\text { EAL apex }\end{array}$ & $\begin{array}{c}\text { Past R or } \\
\text { EAL apex }\end{array}$ & Total \\
\hline $\begin{array}{c}\text { Board } \\
\text { certified }\end{array}$ & $6.7 \%$ & $1.2 \%$ & $50.6 \%$ & $37.2 \%$ & $4.3 \%$ & $100 \%$ \\
\hline $\begin{array}{c}\text { Non-board } \\
\text { certified }\end{array}$ & $9.3 \%$ & $7.7 \%$ & $48.1 \%$ & $30.1 \%$ & $4.9 \%$ & $100 \%$ \\
\hline Resident & $8.2 \%$ & $6.1 \%$ & $63.3 \%$ & $22.4 \%$ & $0.0 \%$ & $100 \%$ \\
\hline Average & $8.1 \%$ & $4.8 \%$ & $51.0 \%$ & $32.1 \%$ & $4.0 \%$ & $100 \%$ \\
\hline
\end{tabular}


TABLE 17. Level of instrumentation on necrotic pulp with fluctuant swelling and drainage

\begin{tabular}{|c|c|c|c|c|c|c|}
\hline & $\begin{array}{c}0.5 \text { to 1mm } \\
\text { short of R } \\
\text { apex }\end{array}$ & To R apex & $\begin{array}{c}\text { To EAL } \\
\text { apex }\end{array}$ & $\begin{array}{c}0.5 \text { to } 1 \mathrm{~mm} \\
\text { short of } \\
\text { EAL apex }\end{array}$ & $\begin{array}{c}\text { Past R or } \\
\text { EAL apex }\end{array}$ & Total \\
\hline $\begin{array}{c}\text { Board } \\
\text { certified }\end{array}$ & $4.9 \%$ & $1.8 \%$ & $49.1 \%$ & $36.8 \%$ & $7.4 \%$ & $100 \%$ \\
\hline $\begin{array}{c}\text { Non-board } \\
\text { certified }\end{array}$ & $8.9 \%$ & $6.7 \%$ & $49.4 \%$ & $28.9 \%$ & $6.1 \%$ & $100 \%$ \\
\hline Resident & $8.2 \%$ & $4.1 \%$ & $59.2 \%$ & $22.4 \%$ & $6.1 \%$ & $100 \%$ \\
\hline Average & $7.1 \%$ & $4.3 \%$ & $50.5 \%$ & $31.4 \%$ & $6.6 \%$ & $100 \%$ \\
\hline
\end{tabular}

TABLE 18. Level of instrumentation on necrotic pulp with fluctuant swelling, no drainage

\begin{tabular}{|c|c|c|c|c|c|c|}
\hline & $\begin{array}{c}0.5 \text { to 1mm } \\
\text { short of R } \\
\text { apex }\end{array}$ & To R apex & $\begin{array}{c}\text { To EAL } \\
\text { apex }\end{array}$ & $\begin{array}{c}0.5 \text { to } 1 \mathrm{~mm} \\
\text { short of } \\
\text { EAL apex }\end{array}$ & $\begin{array}{c}\text { Past R or } \\
\text { EAL apex }\end{array}$ & Total \\
\hline $\begin{array}{c}\text { Board } \\
\text { certified }\end{array}$ & $4.9 \%$ & $1.8 \%$ & $49.4 \%$ & $36.0 \%$ & $7.9 \%$ & $100 \%$ \\
\hline $\begin{array}{c}\text { Non-board } \\
\text { certified }\end{array}$ & $8.8 \%$ & $6.6 \%$ & $47.0 \%$ & $28.2 \%$ & $9.4 \%$ & $100 \%$ \\
\hline Resident & $8.2 \%$ & $6.1 \%$ & $59.2 \%$ & $22.4 \%$ & $4.1 \%$ & $100 \%$ \\
\hline Average & $7.1 \%$ & $4.6 \%$ & $49.5 \%$ & $30.7 \%$ & $8.1 \%$ & $100 \%$ \\
\hline
\end{tabular}

TABLE 19. Level of instrumentation on necrotic pulp with diffuse facial swelling, drainage through canal

\begin{tabular}{|c|c|c|c|c|c|c|}
\hline & $\begin{array}{c}0.5 \text { to 1mm } \\
\text { short of R } \\
\text { apex }\end{array}$ & To R apex & $\begin{array}{c}\text { To EAL } \\
\text { apex }\end{array}$ & $\begin{array}{c}0.5 \text { to 1mm } \\
\text { short of } \\
\text { EAL apex }\end{array}$ & $\begin{array}{c}\text { Past R or } \\
\text { EAL apex }\end{array}$ & Total \\
\hline $\begin{array}{c}\text { Board } \\
\text { certified }\end{array}$ & $4.9 \%$ & $1.8 \%$ & $48.8 \%$ & $36.6 \%$ & $7.9 \%$ & $100 \%$ \\
\hline $\begin{array}{c}\text { Non-board } \\
\text { certified }\end{array}$ & $8.9 \%$ & $6.7 \%$ & $47.5 \%$ & $29.1 \%$ & $7.8 \%$ & $100 \%$ \\
\hline Resident & $8.2 \%$ & $6.1 \%$ & $59.2 \%$ & $22.4 \%$ & $4.1 \%$ & $100 \%$ \\
\hline Average & $7.1 \%$ & $4.6 \%$ & $49.5 \%$ & $31.4 \%$ & $7.4 \%$ & $100 \%$ \\
\hline
\end{tabular}


TABLE 20. Level of instrumentation on necrotic pulp with diffuse facial swelling, no drainage

\begin{tabular}{|c|c|c|c|c|c|c|}
\hline & $\begin{array}{c}0.5 \text { to } 1 \mathrm{~mm} \\
\text { short of R } \\
\text { apex }\end{array}$ & To R apex & $\begin{array}{c}\text { To EAL } \\
\text { apex }\end{array}$ & $\begin{array}{c}0.5 \text { to } 1 \mathrm{~mm} \\
\text { short of } \\
\text { EAL apex }\end{array}$ & $\begin{array}{c}\text { Past R or } \\
\text { EAL apex }\end{array}$ & Total \\
\hline $\begin{array}{c}\text { Board } \\
\text { certified }\end{array}$ & $4.9 \%$ & $1.9 \%$ & $48.1 \%$ & $36.4 \%$ & $8.6 \%$ & $100 \%$ \\
\hline $\begin{array}{c}\text { Non-board } \\
\text { certified }\end{array}$ & $8.9 \%$ & $6.7 \%$ & $47.2 \%$ & $28.9 \%$ & $8.3 \%$ & $100 \%$ \\
\hline Resident & $8.3 \%$ & $6.3 \%$ & $60.4 \%$ & $20.8 \%$ & $4.2 \%$ & $100 \%$ \\
\hline Average & $7.2 \%$ & $4.6 \%$ & $49.2 \%$ & $31.0 \%$ & $7.9 \%$ & $100 \%$ \\
\hline
\end{tabular}

Regarding necrotic cases and adjunct treatment modalities (leaving the tooth open, incision and drainage, inserting drain, and artifisutation) the average majority between respondents who are board certified, non-board certified, and residents were incision and drainage. The results are shown in Table 21.

TABLE 21. Adjunct treatment modalities

\begin{tabular}{|l|c|c|c|c|}
\hline & $\begin{array}{c}\text { Leave Tooth } \\
\text { Open }\end{array}$ & $\begin{array}{c}\text { Incision and } \\
\text { Drainage }\end{array}$ & $\begin{array}{c}\text { Insert } \\
\text { Drain }\end{array}$ & Artifistulation \\
\hline $\begin{array}{l}\text { Necrotic pulp, fluctuant } \\
\text { swelling, no drainage }\end{array}$ & $2.6 \%$ & $95.9 \%$ & $3.2 \%$ & $3.2 \%$ \\
\hline $\begin{array}{l}\text { Necrotic pulp, fluctuant } \\
\text { swelling, with drainage }\end{array}$ & $12.0 \%$ & $87.3 \%$ & $2.1 \%$ & $5.3 \%$ \\
\hline $\begin{array}{l}\text { Necrotic pulp, diffuse } \\
\text { facial swelling, no } \\
\text { drainage }\end{array}$ & $9.0 \%$ & $87.1 \%$ & $6.3 \%$ & $6.6 \%$ \\
\hline $\begin{array}{l}\text { Necrotic pulp, diffuse } \\
\text { facial swelling, drainage } \\
\text { through canal }\end{array}$ & $27.1 \%$ & $69.2 \%$ & $4.6 \%$ & $7.5 \%$ \\
\hline
\end{tabular}

Note: multiple choices were permitted 


\section{Discussion}

The overall preference in recommended analgesia was ibuprofen with $99.2 \%$ of all participants indicating that choice. The second most recommended analgesia was acetaminophen. It was recommended by $66.4 \%$ of all participants. This is in agreement with the systematic study by Zanjir et al., (2020) who found either NSAIDs alone or in combination with acetaminophen after completing a root canal, resulted in a significant decrease in postoperative pain for patients with pulpal necrosis or irreversible pulpitis, compared to opioids, corticosteroids, and benzodiazepines (19). This is, therefore, an evidence-based practice used by almost all of the participants surveyed.

The preferences for antibiotics were: Amoxicillin, Clindamycin, and Augmentin (88.3\%, $65.1 \%, 31.8 \%$, respectively). A national survey was conducted by Germack et al., (2016) to members of the American Association of Endodontists regarding antibiotic use. In this study they found a significant shift from prescribing penicillin $\mathrm{V}$ to amoxicillin as endodontists first choice of antibiotic and substantial increase in clindamycin for penicillin-allergic patients (42). However, results from the survey by Germack, and this study show that many participants may not be following the AAE Colleagues of Excellence 2019 position statement recommending Azithromycin (Augmentin with Clavulanic acid) over Clindamycin for penicillin-allergenic patients (22). This is a concern as it may indicate that the participants were not aware of the evidence-based recommendation to avoid clindamycin due to the risk of fatal colitis and black box warning for diarrhea associated with clostridium difficile (22).

Participants at all levels of education had similar choices for supplemental analgesia. Although it failed to reach significance, PDL was chosen by $35.6 \%$ of participants with articaine infiltration as a close second. This result is in agreement with evidence provided by 
Walton and Torabinejad (1992) who recommended using PDL injections if profound anesthesia did not occur with standard IANB injections, and Kanaa (2021) who recommended buccal infiltration with $4 \%$ articaine $(26,27)$.

The board certified endodontists were more likely to use CBCT $(P<0.05)$ for emergency endodontic procedures than non-board certified and residents. In a study that supports the use of $\mathrm{CBCT}$, researchers were able to detect $85.4 \%$ of maxillary molars with 2 root canals in the mesiobuccal root, whereas most treated maxillary molars without CBCT have the potential of having miss one of the two canals. (43). This study shows the impact CBCT can have on missed anatomy that a standard PA cannot identify. In a different study by Patel et al., (2021) they found higher sensitivity of CBCT imaging on traumatic dental injuries compared to conventional radiographic techniques including periapical and occlusal radiographs (44).

Considering microscope use during emergency treatments, board certified endodontists were more likely than non-board certified endodontists or residents to always use a microscope $(P<0.05)$ across all levels of education. In addition to the study mentioned earlier by Monea et al. (2015) with improved treatment outcomes of root canal therapy when using a microscope (36), a study by Khalighinejad et al., (2017) showed the MB root was 3 times more likely to present with a periapical radiolucency at the time of retreatment if initial NSRCT was performed without the use of a microscope (45).

Participants at all levels of education had similar choices for time between treatment $(P>$ 0.05). Overall $37.9 \%$ chose completing treatment in $1-2$ weeks and $29.9 \%$ chose to complete treatment in a single visit. Although there is strong evidence for single visit treatment to save patients from multiple visits while having no significant difference in healing rates and decreased incidence of post-operative complications (15), many of the participants in this 
survey did not choose single visit. Further studies to evaluate current treatment outcome and the decision behind choosing between these two modalities may be needed.

Regardless of the pulpitis condition - irreversible or necrotic, and presence or absence of swelling, the majority of respondents chose complete instrumentation as the primary choice for all levels of education. This agrees with the 2009 survey that was completed on current trends in the endodontic practice; the results suggested complete instrumentation regardless of the type of swelling (fluctuant versus diffuse) and chose not to leave the tooth open (5).

Residents were more likely to treat irreversible pulpitis with acute apical periodontitis with an electronic apex locator compared to board certified and non-board certified $(P<$ 0.05). However, the average response from all levels of education, instrumented to the electronic apex locator for all the diagnoses. In a study by ElAyouti (2002), they found a working length overestimation of $51 \%$ when using radiographs versus $21 \%$ when using an electronic apex locator to find the working length, a statistical significance (46), showing evidence-based research on the importance of using an electronic apex locator to prevent over-instrumentation. Additionally, the reduced exposure to radiation by using apex locator may be a factor that motivates a practitioner's decision to choose the electronic apex locator over radiographic working length.

As for treating necrotic cases with adjunct modalities such as leaving tooth open, incision and drainage, insert drain, and artifistulation, the majority response was incision and drainage. This agrees with the AAE's recommendation of incision and drainage on the management of soft tissue edema with odontogenic origin (22). This technique for management was also recommended by Nusstein (2002) for decreased postoperative pain and discomfort associated with drainage (32). 


\section{CHAPTER V}

\section{Conclusion}

\section{These were the trends that were noted in this study:}

- The most recommended analgesic was ibuprofen. This is an evidence-based practice that was followed by almost all of the participants

- The most recommended antibiotic was amoxicillin followed by clindamycin. The use of clindamycin is not recommended by the AAE and is no longer an evidence-based practice. More educational efforts are needed to reach residents and endodontists

- Participants at all levels of education had similar choices in supplemental anesthesia $(P>0.05)$

- Board certified endodontists were most likely to use CBCT during endodontic emergencies compared to non-board certified and residents $(P<0.05)$

- Considering microscope use during emergency treatments, board certified endodontists were more likely than non-board certified endodontists or residents to always use a microscope $(P<0.05)$

- Participants at all levels of education had similar choices for time between treatment, with 1-2 weeks of waiting between initial and final treatments $(P>0.05)$

- Residents were more likely to treat to the apex using the electronic apex locator than board-certified or non-board certified endodontists specifically for irreversible pulpitis with acute apical periodontitis $(P<0.05)$

- Participants at all levels of education on average treat to the apex using the electronic apex locator $(P>0.05)$ 
- Participants at all levels of education on average completed instrumentation for all diagnoses $(P>0.05)$

- Among the adjunct treatment modality choices, the ranking was I\&D, leave tooth open, insert drain, and artifistulation 


\section{References}

1. American Association of Endodontists: Glossary of Endodontic Terms, ed 9, Chicago, 2015, American Association of Endodontists.

2. Dorn SO, Moodnik RM, Feldman MJ, Borden BG: Treatment of the endodontic emergency: a report based on questionnaire - part I, J Endod 1997; 3: 94-100.

3. Dorn SO, Moodnik RM, Feldman MJ, Borden BG: Treatment of the endodontic emergency: a report based on a questionnaire - part II, J Endod 1997; 3: 153-156.

4. Gatewood RS, Himel VT, Dorn S: Treatment of the endodontic emergency: a decade later, J Endod 1990; 16:284-91.

5. Lee M, Winkler J, Hartwell G, et al: Current trends in endodontic practice: emergency treatments and technological armamentarium, J Endod, 2009; 35: 35-39.

6. Singh V, Nikhil V, Singh A, Yadav S: An in vivo comparative evaluation to determine the accuracy of working length between radiographic and electronic apex locators, Indian J Dent Res, 2012; 23:359-62.

7. AAE. American Association of Endodontists Colleagues of Excellence: Endodontic Diagnosis. Colleagues Excell. 2013: 1-6.

8. Nyerere JW, Matee MI, Simon EN. Emergency pulpotomy in relieving acute dental pain among Tanzanian patients. BMC Oral Health 2006; 6:1.

9. Hasselgren G, Reit C. Emergency pulpotomy: pain relieving effect with and without the use of sedative dressings. J Endod 1989; 15:254-6.

10. Khan AA, Sun X, Hargreaves KM. Effect of calcium hydroxide on proinflammatory cytokines and neuropeptides. J Endod 2008; 34:1360-3. 
11. Dahlen G, Samuelsson W, Molander A, Reit C. Identification and antimicrobial susceptibility of enterococci isolated from the root canal. Oral Microbiol Immunol 2000; 15:309-12.

12. Katebzadeh N, Sigurdsson A, Trope M. Radiographic evaluation of periapical healing after obturation of infected root canals: an in vivo study. Int Endod J 2000; 33:60-6.

13. Peters LB, Wesselink PR. Periapical healing of endodontically treated teeth in one and two visits obturated in the presence or absence of detectable microorganisms. Int Endod J 2002; 35:660-7.

14. Soltanoff W. A comparative study of the single-visit and the multiple-visit endodontic procedure. J Endod 1978; 4:278-81.

15. Su Y, Wang C, Ye L. Healing rate and post-obturation pain of single-versus multiplevisit endodontic treatment for infected root canals: a systematic review. J Endod. 2011; $37: 125-132$

16. Moreira MS, Anuar ASN, Tedesco TK, Dos Santos M, Morimoto S. Endodontic Treatment in Single and Multiple Visits: An Overview of Systematic Reviews. J Endod $2017 ; 43: 864-870$.

17. Penesis VA, Fitzgerald PI, Fayad MI, Wenckus CS, BeGole EA, Johnson BR. Outcome of one-visit and two-visit endodontic treatment of necrotic teeth with apical periodontitis: a randomized controlled trial with one-year evaluation. J Endod 2008; 34:251-257.

18. Menhinick KA, Gutmann JL, Regan JD, Taylor SE, Buschang PH. The efficacy of pain control following nonsurgical root canal treatment using ibuprofen or a combination of ibuprofen and acetaminophen in a randomized, double blind, placebo-controlled study. Int Endod J 2004; 37:531-41. 
19. Zanjir M, Sgro A, Lighvan NL, Yarascavitch C, Shah P, da Costa B, Azarpazhooh A. Efficacy and safety of postoperative medications in reducing pain after nonsurgical endodontic treatment: a systematic review and network meta-analysis. J Endod 2020; 46:1387-1402.

20. Mickel AK, Wright AP, Chogle S, Jones JJ, Kantorovich I, Curd F. An analysis of current analgesic preferences for endodontic pain management. J Endod 2006; 32:11461154.

21. Durkin MJ, Feng Q, Warren K, Lockhart PB, Thornhill MH, Munshi KD, Henderson RR, Hsueh K, Fraser VJ; Centers for disease control and prevention epicenters. Assessment of inappropriate antibiotic prescribing among a large cohort of general dentists in the United States. J Am Dent Assoc. 2018; 149:372-381.

22. AAE. American Association of Endodontists Colleagues of Excellence: Endodontics and Antibiotic Update. Colleagues Excell. 2019;1-8.

23. Nagle D, Reader A, Beck M, Weaver J. Effect of systemic penicillin on pain in untreated irreversible pulpitis. Oral Surg Oral Med Oral Pathol Oral Radiol Endod 2000; 90:636640.

24. Salvo F, Polimeni G, Moretti U, Conforti A, Leone R, Leoni O, Motola D, Dusi G, Caputi A. Adverse drug reactions related to amoxicillin alone and in association with clavulanic acid: data from spontaneous reporting in Italy. J Antimicrob Chemother 2007; $60: 121-126$

25. Hargreaves K, Keiser K, Local anesthetic failure in endodontics: mechanisms and management. Endod Topics 2002; 1:26-39. 
26. Walton RE, Torabinejad M. Managing local anesthesia problems in the endodontic patient. J Am Dent Assoc 1992; 123:97-102.

27. Kanaa MD, Whitworth JM, Meechan JG. A prospective randomized trial of different supplementary local anesthetic techniques after failure of inferior alveolar nerve block in patients with irreversible pulpitis in mandibular teeth. J Endod 2012; 38:421-425.

28. Fowler S, Drum M, Reader A, Beck M. Anesthetic success of an inferior alveolar nerve block and supplemental articaine buccal infiltration for molars and premolars in patients with symptomatic irreversible pulpitis. J Endod 2016; 42:390-392.

29. Rosenberg PA, Babick PJ, Schertzer L, Leung A. The effect of occlusal reduction on pain after endodontic instrumentation. J Endod 1998; 24:492-6.

30. Henry BM, Fraser JG. Trephination for acute pain management. J Endod 2003; 29:144146.

31. Nist E, Reader A, Beck M. Effect of apical trephination on postoperative pain and swelling in symptomatic necrotic teeth. J Endod 2001; 27:415-420.

32. Nusstein JM, Reader A, Beck M. Effect of drainage upon access on postoperative endodontic pain and swelling in symptomatic necrotic teeth. J Endod 2002; 28:584-588.

33. Beus H, Fowler S, Drum M, Reader A, Nusstein J, Beck M, Jatana C. What is the outcome of an incision and drainage procedure in endodontic patients? A prospective, randomized, single-blind study. J Endod 2018; 44:193-201.

34. Siqueira JF Jr. Microbial causes of endodontic flaure-ups. Int Endod 2003; 36:453-463.

35. Stropko JJ. Canal morphology of maxillary molars: clinical observations of canal configurations. J Endod 1999; 25:446-450. 
36. Monea M, Hantoiu T, Stoica A, Sita D, Sitaru A. The impact of operative microscope on the outcome of endodontic treatment performed by postgraduate students. Eur Sci J 2015; $305-11$.

37. Goldman M, Pearson AH, Darzenta N. Endodontic success: who's reading the radiograph? Oral Surg Oral Med Oral Pathol 1972; 33:432-7.

38. Patel S, Wilson R, Dawood A, Foschi F, Mannocci F. The detection of periapical pathosis using digital periapical radiography and cone beam computed tomography - part 2: a 1-year post treatment follow-up. Int Endod J 2012; 45:711-723.

39. Hassan B, Metska Me, Ozok AR, van der Stelt P, Wesselink PR. Detection of vertical root fractures in endodontically treated teeth by a cone beam computed tomography scan. J Endod 2009; 35:719-22.

40. PA Harris, R Taylor, R Thielke, J Payne, N Gonzalez, JG. Conde, Research electronic data capture (REDCap) - A metadata-driven methodology and workflow process for providing translational research informatic support, J Biomed Inform 2009 Apr; 42:37781.

41. PA Harris, R Taylor, BL Minor, V Elliot, M Fernandez, L O’Neal, L McLeod, G Delacqua, F Delacqua, J Kirby, SN Duda, REDCap Consortium, The REDCap consortium: Building an international community of software partners, J Biomed Inform 2019 May 9 [doi:10.1016/j.jbi.2019.103208]

42. Germack M, Sedgley C, Sabbah W, Whitten B. Antibiotic Use in 2016 by Members of the American Association of Endodontists: Report of a National Survey. J Endod 2017; 43:1615-1622. 
43. Zhang, Yuerong, Xu H, Wang D, Gu Y, Wang J, Tu S, Qiu X, Zhang F, Luo Y, Bai J, Simone G, Zhang G. Assessment of the Second Mesiobuccal Root Canal in Maxillary First Molars: A Cone-Beam Computed Tomographic Study. J Endod 2017; 43:19901996.

44. Patel S, Puri T, Mannocci F, Navai A. Diagnosis and Management of Traumatic Dental Injuries Using Intraoral Radiography and Cone-Beam Computed Tomography: An In Vivo Investigation. J Endod 2021; 46:914-923.

45. Khalighinejad N, Aminoshariae A, Kulild J, Williams K, Wang J, Mickel A. The Effect of the Dental Operating Microscope on the Outcome of Nonsurgical Root canal Treatment: A Retrospective Case-control Study. J Endod 2017; 43:728-732.

46. ElAyouti A, Weiger R, Lost C. The ability of root ZX apex locator to reduce the frequency of overestimated radiographic working length. J Endod 2002; 28:116-9. 


\section{Appendix}

TABLE 1. Most recommended analgesic

\begin{tabular}{ll}
\hline & Response Percent \\
\hline Ibuprofen & $99.2 \%$ \\
Acetaminophen & $66.4 \%$ \\
Vicodin & $10.6 \%$ \\
Other & $10.4 \%$ \\
Tylenol \#3 & $9.1 \%$ \\
Percocet & $2.8 \%$ \\
Lortab & $1.8 \%$ \\
\hline
\end{tabular}

Note: multiple choices were permitted

TABLE 2. Most recommended antibiotic

\begin{tabular}{ll}
\hline & Response Percent \\
\hline Amoxicillin & $88.3 \%$ \\
Clindamycin & $65.1 \%$ \\
Augmentin & $31.8 \%$ \\
Penicillin & $24.4 \%$ \\
Other & $13.2 \%$ \\
Metronidazole & $11.2 \%$ \\
Cephalexin & $7.4 \%$ \\
Erythromycin & $1.3 \%$ \\
\hline
\end{tabular}

Note: multiple choices were permitted

TABLE 3. Most common supplemental anesthesia for irreversible pulpitis

\begin{tabular}{|c|c|c|c|c|c|c|}
\hline & $\begin{array}{c}\text { Articaine } \\
\text { infiltration }\end{array}$ & $\begin{array}{c}\text { Intraosseous } \\
\text { injection }\end{array}$ & $\begin{array}{c}\text { Intrapulpal } \\
\text { injection }\end{array}$ & $\begin{array}{c}\text { Periodontal } \\
\text { ligament } \\
\text { injection }\end{array}$ & None & Total \\
\hline $\begin{array}{c}\text { Board } \\
\text { certified }\end{array}$ & $33.5 \%$ & $23.8 \%$ & $9.1 \%$ & $33.5 \%$ & $0 \%$ & $100 \%$ \\
\hline $\begin{array}{c}\text { Non-board } \\
\text { certified }\end{array}$ & $31.7 \%$ & $16.4 \%$ & $14.2 \%$ & $37.7 \%$ & $0 \%$ & $100 \%$ \\
\hline Resident & $24.5 \%$ & $20.4 \%$ & $18.4 \%$ & $34.7 \%$ & $2.0 \%$ & $100 \%$ \\
\hline Average & $31.6 \%$ & $19.9 \%$ & $12.6 \%$ & $35.6 \%$ & $0.3 \%$ & $100 \%$ \\
\hline
\end{tabular}


TABLE 4. Routine CBCT use for emergency treatments

\begin{tabular}{|c|c|c|c|c|}
\hline & Yes & No & Occasionally & Total \\
\hline Board certified & $47.6 \%$ & $22.6 \%$ & $29.9 \%$ & $100 \%$ \\
\hline $\begin{array}{c}\text { Non-board } \\
\text { certified }\end{array}$ & $30.1 \%$ & $44.3 \%$ & $25.7 \%$ & $100 \%$ \\
\hline Resident & $20.4 \%$ & $42.9 \%$ & $36.7 \%$ & $100 \%$ \\
\hline Average & $36.1 \%$ & $35.1 \%$ & $28.8 \%$ & $100 \%$ \\
\hline
\end{tabular}

TABLE 5. Microscope use for emergency treatments

\begin{tabular}{|c|c|c|c|c|c|c|c|}
\hline & Never & $\begin{array}{c}\text { Less } \\
\text { than } \\
25 \% \text { of } \\
\text { time }\end{array}$ & $\begin{array}{c}25-50 \% \\
\text { of time }\end{array}$ & $\begin{array}{c}50-75 \% \\
\text { of time }\end{array}$ & $\begin{array}{c}\text { Greater } \\
\text { than 75\% } \\
\text { of time }\end{array}$ & Always & Total \\
\hline $\begin{array}{c}\text { Board } \\
\text { certified }\end{array}$ & $1.2 \%$ & $4.3 \%$ & $1.2 \%$ & $2.4 \%$ & $8.5 \%$ & $82.3 \%$ & $100 \%$ \\
\hline $\begin{array}{c}\text { Non- } \\
\text { board } \\
\text { certified }\end{array}$ & $1.1 \%$ & $7.7 \%$ & $4.4 \%$ & $3.3 \%$ & $9.8 \%$ & $73.8 \%$ & $100 \%$ \\
\hline Resident & $6.1 \%$ & $8.2 \%$ & $4.1 \%$ & $12.2 \%$ & $14.3 \%$ & $55.1 \%$ & $100 \%$ \\
\hline Average & $1.8 \%$ & $6.3 \%$ & $3.0 \%$ & $4.0 \%$ & $9.8 \%$ & $75.0 \%$ & $100 \%$ \\
\hline
\end{tabular}

TABLE 6. Length of Time Between Treatment

\begin{tabular}{|c|c|c|c|c|c|c|}
\hline & $\begin{array}{c}\text { Less than 1 } \\
\text { week }\end{array}$ & $1-2$ weeks & $2-3$ weeks & $\begin{array}{c}\text { More than 3 } \\
\text { weeks }\end{array}$ & $\begin{array}{c}\text { Treatment } \\
\text { completed 1 } \\
\text { visit }\end{array}$ & Total \\
\hline $\begin{array}{c}\text { Board } \\
\text { certified }\end{array}$ & $11.1 \%$ & $43.2 \%$ & $16.0 \%$ & $2.5 \%$ & $27.2 \%$ & $100 \%$ \\
\hline $\begin{array}{c}\text { Non-board } \\
\text { certified }\end{array}$ & $16.7 \%$ & $32.2 \%$ & $16.7 \%$ & $1.7 \%$ & $32.8 \%$ & $100 \%$ \\
\hline Resident & $14.3 \%$ & $40.8 \%$ & $14.3 \%$ & $2.0 \%$ & $28.6 \%$ & $100 \%$ \\
\hline Average & $14.1 \%$ & $37.9 \%$ & $16.1 \%$ & $2.0 \%$ & $29.9 \%$ & $100 \%$ \\
\hline
\end{tabular}


TABLE 7. Level of pulp removal on irreversible pulpitis with normal apical tissues

\begin{tabular}{|c|c|c|c|c|c|}
\hline & $\begin{array}{c}\text { Partial } \\
\text { pulpotomy }\end{array}$ & $\begin{array}{c}\text { Complete } \\
\text { pulpotomy }\end{array}$ & Pulpectomy & $\begin{array}{c}\text { Complete } \\
\text { instrumentation }\end{array}$ & Total \\
\hline $\begin{array}{c}\text { Board } \\
\text { certified }\end{array}$ & $2.5 \%$ & $8.6 \%$ & $17.8 \%$ & $71.2 \%$ & $100 \%$ \\
\hline $\begin{array}{c}\text { Non-board } \\
\text { certified }\end{array}$ & $0.5 \%$ & $5.5 \%$ & $20.8 \%$ & $73.2 \%$ & $100 \%$ \\
\hline Resident & $0.0 \%$ & $8.2 \%$ & $24.5 \%$ & $67.3 \%$ & $100 \%$ \\
\hline Average & $1.3 \%$ & $7.1 \%$ & $20.0 \%$ & $71.6 \%$ & $100 \%$ \\
\hline
\end{tabular}

TABLE 8. Level of pulp removal on irreversible pulpitis with acute apical periodontitis

\begin{tabular}{|c|c|c|c|c|c|}
\hline & $\begin{array}{c}\text { Partial } \\
\text { pulpotomy }\end{array}$ & $\begin{array}{c}\text { Complete } \\
\text { pulpotomy }\end{array}$ & Pulpectomy & $\begin{array}{c}\text { Complete } \\
\text { instrumentation }\end{array}$ & Total \\
\hline $\begin{array}{c}\text { Board } \\
\text { certified }\end{array}$ & $0.6 \%$ & $5.5 \%$ & $17.7 \%$ & $76.2 \%$ & $100 \%$ \\
\hline $\begin{array}{c}\text { Non-board } \\
\text { certified }\end{array}$ & $0.0 \%$ & $3.4 \%$ & $20.7 \%$ & $76.0 \%$ & $100 \%$ \\
\hline Resident & $0.0 \%$ & $4.1 \%$ & $20.4 \%$ & $75.5 \%$ & $100 \%$ \\
\hline Average & $0.3 \%$ & $4.3 \%$ & $19.4 \%$ & $76.0 \%$ & $100 \%$ \\
\hline
\end{tabular}

TABLE 9. Level of pulp removal on necrotic pulp with apical periodontitis, no swelling

\begin{tabular}{|c|c|c|c|c|c|}
\hline & $\begin{array}{c}\text { Partial } \\
\text { pulpotomy }\end{array}$ & $\begin{array}{c}\text { Complete } \\
\text { pulpotomy }\end{array}$ & Pulpectomy & $\begin{array}{c}\text { Complete } \\
\text { instrumentation }\end{array}$ & Total \\
\hline $\begin{array}{c}\text { Board } \\
\text { certified }\end{array}$ & $0 \%$ & $3.1 \%$ & $14.8 \%$ & $82.1 \%$ & $100 \%$ \\
\hline $\begin{array}{c}\text { Non-board } \\
\text { certified }\end{array}$ & $0 \%$ & $1.1 \%$ & $17.7 \%$ & $81.2 \%$ & $100 \%$ \\
\hline Resident & $0 \%$ & $2.1 \%$ & $14.9 \%$ & $83.0 \%$ & $100 \%$ \\
\hline Average & $0 \%$ & $2.1 \%$ & $16.2 \%$ & $81.8 \%$ & $100 \%$ \\
\hline
\end{tabular}


TABLE 10. Level of pulp removal on necrotic pulp with fluctuant swelling, no drainage

\begin{tabular}{|c|c|c|c|c|c|}
\hline & $\begin{array}{c}\text { Partial } \\
\text { pulpotomy }\end{array}$ & $\begin{array}{c}\text { Complete } \\
\text { pulpotomy }\end{array}$ & Pulpectomy & $\begin{array}{c}\text { Complete } \\
\text { instrumentation }\end{array}$ & Total \\
\hline $\begin{array}{c}\text { Board } \\
\text { certified }\end{array}$ & $0 \%$ & $3.1 \%$ & $15.3 \%$ & $81.6 \%$ & $100 \%$ \\
\hline $\begin{array}{c}\text { Non-board } \\
\text { certified }\end{array}$ & $0 \%$ & $1.1 \%$ & $18.0 \%$ & $80.9 \%$ & $100 \%$ \\
\hline Resident & $0 \%$ & $2.1 \%$ & $21.3 \%$ & $76.6 \%$ & $100 \%$ \\
\hline Average & $0 \%$ & $2.1 \%$ & $17.3 \%$ & $80.7 \%$ & $100 \%$ \\
\hline
\end{tabular}

TABLE 11. Level of pulp removal on necrotic pulp with fluctuant swelling, with drainage

\begin{tabular}{|c|c|c|c|c|c|}
\hline & $\begin{array}{c}\text { Partial } \\
\text { pulpotomy }\end{array}$ & $\begin{array}{c}\text { Complete } \\
\text { pulpotomy }\end{array}$ & Pulpectomy & $\begin{array}{c}\text { Complete } \\
\text { instrumentation }\end{array}$ & Total \\
\hline $\begin{array}{c}\text { Board } \\
\text { certified }\end{array}$ & $0 \%$ & $3.0 \%$ & $15.9 \%$ & $81.1 \%$ & $100 \%$ \\
\hline $\begin{array}{c}\text { Non-board } \\
\text { certified }\end{array}$ & $0 \%$ & $1.1 \%$ & $19.8 \%$ & $79.1 \%$ & $100 \%$ \\
\hline Resident & $0 \%$ & $2.1 \%$ & $25.5 \%$ & $72.3 \%$ & $100 \%$ \\
\hline Average & $0 \%$ & $2.1 \%$ & $18.8 \%$ & $79.1 \%$ & $100 \%$ \\
\hline
\end{tabular}

TABLE 12. Level of pulp removal on necrotic pulp with diffuse facial swelling, no drainage

\begin{tabular}{|c|c|c|c|c|c|}
\hline & $\begin{array}{c}\text { Partial } \\
\text { pulpotomy }\end{array}$ & $\begin{array}{c}\text { Complete } \\
\text { pulpotomy }\end{array}$ & Pulpectomy & $\begin{array}{c}\text { Complete } \\
\text { instrumentation }\end{array}$ & Total \\
\hline $\begin{array}{c}\text { Board } \\
\text { certified }\end{array}$ & $0 \%$ & $3.1 \%$ & $15.4 \%$ & $81.5 \%$ & $100 \%$ \\
\hline $\begin{array}{c}\text { Non-board } \\
\text { certified }\end{array}$ & $0 \%$ & $1.1 \%$ & $21.0 \%$ & $77.8 \%$ & $100 \%$ \\
\hline Resident & $0 \%$ & $0.0 \%$ & $23.4 \%$ & $76.6 \%$ & $100 \%$ \\
\hline Average & $0 \%$ & $1.8 \%$ & $19.0 \%$ & $79.2 \%$ & $100 \%$ \\
\hline
\end{tabular}


TABLE 13. Level of pulp removal on necrotic pulp with diffuse facial swelling, drainage through canal

\begin{tabular}{|c|c|c|c|c|c|}
\hline & $\begin{array}{c}\text { Partial } \\
\text { pulpotomy }\end{array}$ & $\begin{array}{c}\text { Complete } \\
\text { pulpotomy }\end{array}$ & Pulpectomy & $\begin{array}{c}\text { Complete } \\
\text { instrumentation }\end{array}$ & Total \\
\hline $\begin{array}{c}\text { Board } \\
\text { certified }\end{array}$ & $0 \%$ & $3.1 \%$ & $17.3 \%$ & $79.6 \%$ & $100 \%$ \\
\hline $\begin{array}{c}\text { Non-board } \\
\text { certified }\end{array}$ & $0 \%$ & $1.1 \%$ & $22.5 \%$ & $76.4 \%$ & $100 \%$ \\
\hline Resident & $0 \%$ & $0.0 \%$ & $29.2 \%$ & $70.8 \%$ & $100 \%$ \\
\hline Average & $0 \%$ & $1.8 \%$ & $21.1 \%$ & $77.1 \%$ & $100 \%$ \\
\hline
\end{tabular}

TABLE 14. Level of instrumentation on irreversible pulpitis with normal apical tissues

\begin{tabular}{|c|c|c|c|c|c|c|}
\hline & $\begin{array}{c}0.5 \text { to } 1 \mathrm{~mm} \\
\text { short of R } \\
\text { apex }\end{array}$ & To R apex & $\begin{array}{c}\text { To EAL } \\
\text { apex }\end{array}$ & $\begin{array}{c}0.5 \text { to } 1 \mathrm{~mm} \\
\text { short of } \\
\text { EAL apex }\end{array}$ & $\begin{array}{c}\text { Past R or } \\
\text { EAL apex }\end{array}$ & Total \\
\hline $\begin{array}{c}\text { Board } \\
\text { certified }\end{array}$ & $7.9 \%$ & $0.6 \%$ & $47.0 \%$ & $40.9 \%$ & $3.7 \%$ & $100 \%$ \\
\hline $\begin{array}{c}\text { Non-board } \\
\text { certified }\end{array}$ & $10.4 \%$ & $6.0 \%$ & $48.1 \%$ & $32.8 \%$ & $2.7 \%$ & $100 \%$ \\
\hline Resident & $10.2 \%$ & $4.1 \%$ & $61.2 \%$ & $24.5 \%$ & $0.0 \%$ & $100 \%$ \\
\hline Average & $9.3 \%$ & $3.5 \%$ & $49.2 \%$ & $35.1 \%$ & $2.8 \%$ & $100 \%$ \\
\hline
\end{tabular}

TABLE 15. Level of instrumentation on irreversible pulpitis with acute apical periodontitis

\begin{tabular}{|c|c|c|c|c|c|c|}
\hline & $\begin{array}{c}0.5 \text { to } 1 \mathrm{~mm} \\
\text { short of R } \\
\text { apex }\end{array}$ & To R apex & $\begin{array}{c}\text { To EAL } \\
\text { apex }\end{array}$ & $\begin{array}{c}0.5 \text { to } 1 \mathrm{~mm} \\
\text { short of } \\
\text { EAL apex }\end{array}$ & $\begin{array}{c}\text { Past R or } \\
\text { EAL apex }\end{array}$ & Total \\
\hline $\begin{array}{c}\text { Board } \\
\text { certified }\end{array}$ & $6.7 \%$ & $1.2 \%$ & $46.6 \%$ & $42.3 \%$ & $3.1 \%$ & $100 \%$ \\
\hline $\begin{array}{c}\text { Non-board } \\
\text { certified }\end{array}$ & $9.3 \%$ & $7.1 \%$ & $49.2 \%$ & $31.1 \%$ & $3.3 \%$ & $100 \%$ \\
\hline Resident & $8.2 \%$ & $6.1 \%$ & $61.2 \%$ & $24.5 \%$ & $0.0 \%$ & $100 \%$ \\
\hline Average & $8.1 \%$ & $4.6 \%$ & $49.6 \%$ & $34.9 \%$ & $2.8 \%$ & $100 \%$ \\
\hline
\end{tabular}


TABLE 16. Level of instrumentation on necrotic pulp with acute apical periodontitis, no swelling

\begin{tabular}{|c|c|c|c|c|c|c|}
\hline & $\begin{array}{c}0.5 \text { to } 1 \mathrm{~mm} \\
\text { short of R } \\
\text { apex }\end{array}$ & To R apex & $\begin{array}{c}\text { To EAL } \\
\text { apex }\end{array}$ & $\begin{array}{c}0.5 \text { to } 1 \mathrm{~mm} \\
\text { short of } \\
\text { EAL apex }\end{array}$ & $\begin{array}{c}\text { Past R or } \\
\text { EAL apex }\end{array}$ & Total \\
\hline $\begin{array}{c}\text { Board } \\
\text { certified }\end{array}$ & $6.7 \%$ & $1.2 \%$ & $50.6 \%$ & $37.2 \%$ & $4.3 \%$ & $100 \%$ \\
\hline $\begin{array}{c}\text { Non-board } \\
\text { certified }\end{array}$ & $9.3 \%$ & $7.7 \%$ & $48.1 \%$ & $30.1 \%$ & $4.9 \%$ & $100 \%$ \\
\hline Resident & $8.2 \%$ & $6.1 \%$ & $63.3 \%$ & $22.4 \%$ & $0.0 \%$ & $100 \%$ \\
\hline Average & $8.1 \%$ & $4.8 \%$ & $51.0 \%$ & $32.1 \%$ & $4.0 \%$ & $100 \%$ \\
\hline
\end{tabular}

TABLE 17. Level of instrumentation on necrotic pulp with fluctuant swelling and drainage

\begin{tabular}{|c|c|c|c|c|c|c|}
\hline & $\begin{array}{c}0.5 \text { to 1mm } \\
\text { short of R } \\
\text { apex }\end{array}$ & To R apex & $\begin{array}{c}\text { To EAL } \\
\text { apex }\end{array}$ & $\begin{array}{c}0.5 \text { to } 1 \mathrm{~mm} \\
\text { short of } \\
\text { EAL apex }\end{array}$ & $\begin{array}{c}\text { Past R or } \\
\text { EAL apex }\end{array}$ & Total \\
\hline $\begin{array}{c}\text { Board } \\
\text { certified }\end{array}$ & $4.9 \%$ & $1.8 \%$ & $49.1 \%$ & $36.8 \%$ & $7.4 \%$ & $100 \%$ \\
\hline $\begin{array}{c}\text { Non-board } \\
\text { certified }\end{array}$ & $8.9 \%$ & $6.7 \%$ & $49.4 \%$ & $28.9 \%$ & $6.1 \%$ & $100 \%$ \\
\hline Resident & $8.2 \%$ & $4.1 \%$ & $59.2 \%$ & $22.4 \%$ & $6.1 \%$ & $100 \%$ \\
\hline Average & $7.1 \%$ & $4.3 \%$ & $50.5 \%$ & $31.4 \%$ & $6.6 \%$ & $100 \%$ \\
\hline
\end{tabular}

TABLE 18. Level of instrumentation on necrotic pulp with fluctuant swelling, no drainage

\begin{tabular}{|c|c|c|c|c|c|c|}
\hline & $\begin{array}{c}0.5 \text { to 1mm } \\
\text { short of R } \\
\text { apex }\end{array}$ & To R apex & $\begin{array}{c}\text { To EAL } \\
\text { apex }\end{array}$ & $\begin{array}{c}0.5 \text { to 1mm } \\
\text { short of } \\
\text { EAL apex }\end{array}$ & $\begin{array}{c}\text { Past R or } \\
\text { EAL apex }\end{array}$ & Total \\
\hline $\begin{array}{c}\text { Board } \\
\text { certified }\end{array}$ & $4.9 \%$ & $1.8 \%$ & $49.4 \%$ & $36.0 \%$ & $7.9 \%$ & $100 \%$ \\
\hline $\begin{array}{c}\text { Non-board } \\
\text { certified }\end{array}$ & $8.8 \%$ & $6.6 \%$ & $47.0 \%$ & $28.2 \%$ & $9.4 \%$ & $100 \%$ \\
\hline Resident & $8.2 \%$ & $6.1 \%$ & $59.2 \%$ & $22.4 \%$ & $4.1 \%$ & $100 \%$ \\
\hline Average & $7.1 \%$ & $4.6 \%$ & $49.5 \%$ & $30.7 \%$ & $8.1 \%$ & $100 \%$ \\
\hline
\end{tabular}


TABLE 19. Level of instrumentation on necrotic pulp with diffuse facial swelling, drainage through canal

\begin{tabular}{|c|c|c|c|c|c|c|}
\hline & $\begin{array}{c}0.5 \text { to } 1 \mathrm{~mm} \\
\text { short of R } \\
\text { apex }\end{array}$ & To R apex & $\begin{array}{c}\text { To EAL } \\
\text { apex }\end{array}$ & $\begin{array}{c}0.5 \text { to } 1 \mathrm{~mm} \\
\text { short of } \\
\text { EAL apex }\end{array}$ & $\begin{array}{c}\text { Past R or } \\
\text { EAL apex }\end{array}$ & Total \\
\hline $\begin{array}{c}\text { Board } \\
\text { certified }\end{array}$ & $4.9 \%$ & $1.8 \%$ & $48.8 \%$ & $36.6 \%$ & $7.9 \%$ & $100 \%$ \\
\hline $\begin{array}{c}\text { Non-board } \\
\text { certified }\end{array}$ & $8.9 \%$ & $6.7 \%$ & $47.5 \%$ & $29.1 \%$ & $7.8 \%$ & $100 \%$ \\
\hline Resident & $8.2 \%$ & $6.1 \%$ & $59.2 \%$ & $22.4 \%$ & $4.1 \%$ & $100 \%$ \\
\hline Average & $7.1 \%$ & $4.6 \%$ & $49.5 \%$ & $31.4 \%$ & $7.4 \%$ & $100 \%$ \\
\hline
\end{tabular}

TABLE 20. Level of instrumentation on necrotic pulp with diffuse facial swelling, no drainage

\begin{tabular}{|c|c|c|c|c|c|c|}
\hline & $\begin{array}{c}0.5 \text { to } 1 \mathrm{~mm} \\
\text { short of R } \\
\text { apex }\end{array}$ & To R apex & $\begin{array}{c}\text { To EAL } \\
\text { apex }\end{array}$ & $\begin{array}{c}0.5 \text { to } 1 \mathrm{~mm} \\
\text { short of } \\
\text { EAL apex }\end{array}$ & $\begin{array}{c}\text { Past R or } \\
\text { EAL apex }\end{array}$ & Total \\
\hline $\begin{array}{c}\text { Board } \\
\text { certified }\end{array}$ & $4.9 \%$ & $1.9 \%$ & $48.1 \%$ & $36.4 \%$ & $8.6 \%$ & $100 \%$ \\
\hline $\begin{array}{c}\text { Non-board } \\
\text { certified }\end{array}$ & $8.9 \%$ & $6.7 \%$ & $47.2 \%$ & $28.9 \%$ & $8.3 \%$ & $100 \%$ \\
\hline Resident & $8.3 \%$ & $6.3 \%$ & $60.4 \%$ & $20.8 \%$ & $4.2 \%$ & $100 \%$ \\
\hline Average & $7.2 \%$ & $4.6 \%$ & $49.2 \%$ & $31.0 \%$ & $7.9 \%$ & $100 \%$ \\
\hline
\end{tabular}


TABLE 21. Adjunct treatment modalities

\begin{tabular}{|l|c|c|c|c|}
\hline & $\begin{array}{c}\text { Leave Tooth } \\
\text { Open }\end{array}$ & $\begin{array}{c}\text { Incision and } \\
\text { Drainage }\end{array}$ & $\begin{array}{c}\text { Insert } \\
\text { Drain }\end{array}$ & Artifistulation \\
\hline $\begin{array}{l}\text { Necrotic pulp, fluctuant } \\
\text { swelling, no drainage }\end{array}$ & $2.6 \%$ & $95.9 \%$ & $3.2 \%$ & $3.2 \%$ \\
\hline $\begin{array}{l}\text { Necrotic pulp, fluctuant } \\
\text { swelling, with drainage }\end{array}$ & $12.0 \%$ & $87.3 \%$ & $2.1 \%$ & $5.3 \%$ \\
\hline $\begin{array}{l}\text { Necrotic pulp, diffuse } \\
\text { facial swelling, no } \\
\text { drainage }\end{array}$ & $9.0 \%$ & $87.1 \%$ & $6.3 \%$ & $6.6 \%$ \\
\hline $\begin{array}{l}\text { Necrotic pulp, diffuse } \\
\text { facial swelling, drainage } \\
\text { through canal }\end{array}$ & $27.1 \%$ & $69.2 \%$ & $4.6 \%$ & $7.5 \%$ \\
\hline
\end{tabular}

Note: multiple choices were permitted 